\title{
Mobility of REE from a hyperacid brine to secondary minerals precipitated in a volcanic hydrothermal system: Kawah Ijen crater lake (Java, Indonesia)
}

\author{
Claudio Inguaggiato ${ }^{\mathrm{a}, *}$, Sabrina Pappaterra ${ }^{\mathrm{b}}$, Loic Peiffer $^{\mathrm{a}}$, Carmine Apollaro ${ }^{\mathrm{b}}$, Lorenzo Brusca ${ }^{\mathrm{c}}$, \\ Rosanna De Rosa ${ }^{\mathrm{b}}$, Dmitri Rouwet ${ }^{\mathrm{d}}$, Corentin Caudron ${ }^{\mathrm{e}}$, Suparjan ${ }^{\mathrm{f}}$

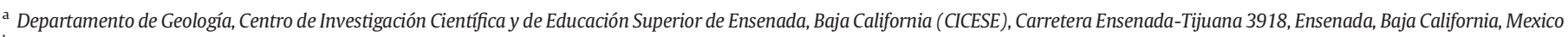 \\ b Dipartimento di Biologia Ecologia e Scienze della terra, Università della Calabria, via Pietro Bucci 87036, Arcavacata di Rende, Cosenza, Italy \\ c Istituto Nazionale di Geofisica e Vulcanologia, Sezione di Palermo, Via U. La Malfa, 153, 90146 Palermo, Italy \\ d Istituto Nazionale di Geofisica e Vulcanologia, Sezione di Bologna, Via Donato Creti 12, Bologna, Italy \\ e Univ. Grenoble Alpes, CNRS, IRD, IFSTTAR, ISTerre, 38000 Grenoble, France, Univ. Savoie Mont Blanc, 24-28 Avenue du Lac d'Annecy, 73370 Le Bourget-du-Lac, France \\ ${ }^{\mathrm{f}}$ Centre for Volcanology and Geological Hazard Mitigation, Geological Agency, Ministry of Energy and Mineral Resources, Bandung, Indonesia
}

\section{H I G H L I G H T S}

- Hyperacid lakes hosted by Kawah Ijen and Poás volcanoes have high REE concentration.

- Sulphate minerals precipitation from hyperacid waters can induce REE fractionation.

- Gypsum precipitation removes preferentially LREE than HREE from hyperacid water.

\section{A R T I C L E I N F O}

\section{Article history:}

Received 17 February 2020

Received in revised form 5 May 2020

Accepted 9 June 2020

Available online 12 June 2020

Editor: José Virgílio Cruz

\section{Keywords:}

Kawah Ijen volcano

Poás volcano

Rare Earth Elements
G R A P H I C A L A B S T R A C T

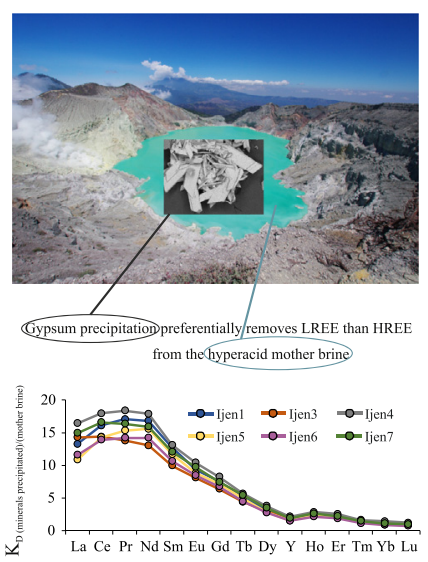

\begin{abstract}
A B S T R A C T
Rare Earth Elements (REE; lanthanides and yttrium) are elements with high economic interest because they are critical elements for modern technologies. This study mainly focuses on the geochemical behavior of REE in hyperacid sulphate brines in volcanic-hydrothermal systems, where the precipitation of sulphate minerals occurs. Kawah Ijen lake, a hyperacid brine hosted in the Ijen caldera (Indonesia), was used as natural laboratory. $\sum$ REE concentration in the lake water is high, ranging from 5.86 to $6.52 \mathrm{mg} \mathrm{kg}^{-1}$. The REE pattern of lake waters normalized to the average local volcanic rock is flat, suggesting isochemical dissolution. Minerals spontaneously precipitated in laboratory at $25^{\circ} \mathrm{C}$ from water samples of Kawah Ijen were identified by XRD as gypsum. Microprobe analyses and the chemical composition of major constituents allow to identify possible other minerals precipitated: jarosite, Al-sulphate and Sr, Ba-sulphate. $\sum$ REE concentration in minerals precipitated (mainly gypsum) range from 59.53 to $78.64 \mathrm{mg} \mathrm{kg}^{-1}$. The REE patterns of minerals precipitated normalized to the average local magmatic rock show enrichment in LREE. The REE distribution coefficient $\left(K_{\mathrm{D}}\right)$, obtained from a ratio of its
\end{abstract}

\footnotetext{
* Corresponding author.

E-mail address: inguaggiato@cicese.mx (C. Inguaggiato).
} 
Hyperacid crater lake Gypsum precipitation REE fractionation concentration in the minerals precipitated (mainly gypsum) and the lake water, shows higher values for LREE than HREE. $\mathrm{K}_{\mathrm{D} \text {-LREE }} / \mathrm{K}_{\mathrm{D} \text {-HREE }}$ increases in the studied samples when the concentrations of $\mathrm{BaO}, \mathrm{MgO}, \mathrm{Fe}_{2} \mathrm{O}_{3}$, $\mathrm{Al}_{2} \mathrm{O}_{3}, \mathrm{Na}_{2} \mathrm{O}$ and the sum of total oxides (except $\mathrm{SO}_{3}$ and $\mathrm{CaO}$ ) decrease in the solid phase. The presence of secondary minerals different than gypsum can be the cause of the distribution coefficient variations.

High concentrations of REE in Kawah Ijen volcanic lake have to enhance the interest on these environments as possible REE reservoir, stimulating future investigations. The comparison of the $\mathrm{K}_{\mathrm{D}}$ calculated for REE after mineral precipitation (mainly gypsum) from Kawah Ijen and Poás hyperacid volcanic lakes allow to generalize that the gypsum precipitation removes the LREE from water.

@ 2020 Elsevier B.V. All rights reserved.

\section{Introduction}

The high demand for Rare Earth Elements (REE; lanthanides and yttrium) as a result of high technology applications has increased the interest in REE behavior in natural systems. In addition, the REE make useful tracers for geochemical processes and anthropogenic contamination (Bau and Dulski, 1996; Johannesson et al., 1997; Moreno et al., 2008; Emsbo et al., 2015; Varekamp, 2015; Inguaggiato et al., 2016, 2017; Censi et al., 2017a, 2017b, 2017c, 2018; Rillard et al., 2019).

The economic importance of REE is mainly due to the application of these elements in modern technologies, including green technologies. The REE are used for production of hybrid automobiles, wind turbines, rechargeable batteries, medical lasers, portable X-ray machines, magnetic resonance imagery (MRI) contrast agents, etc. (Balaram, 2019). The high demand of REE justifies the need to prospect for natural reservoirs. Kato et al. (2011) reported the composition of 2000 seafloor sediments sampled at different sites of the Pacific Ocean and estimated that deep-sea mud can supply a high amount of REE. The amount of REE in an area of one square kilometer is almost one-fifth of the current world annual consumption (Kato et al., 2011). Recently, researchers identified some "waste materials" as potential resource for REE, e.g. coal fly ash (Franus et al., 2015) and phosphogypsum (Liang et al., 2017). Phosphogypsum is a byproduct obtained by processing phosphate minerals using sulfuric acid in order to produce phosphoric acid for the fertilizer production. $\sum$ REE concentrations of $218.42 \mathrm{ppm}$ and $224.93 \mathrm{ppm}$ were found in a Florida phosphogypsum sample and in a Tunisian phosphogypsum sample, respectively (Hammas-Nasri et al., 2016; Liang et al., 2017). Since phosphogypsum represents a waste material, with impurities of other metals such as $\mathrm{As}, \mathrm{Cu}, \mathrm{Cr}, \mathrm{Zn}, \mathrm{Cd}, \mathrm{U}, \mathrm{Pb}, \mathrm{Hg}$, $\mathrm{Se}$, the improper disposal of phosphogypsum could cause environmental pollution (Tayibi et al., 2009; Liang et al., 2017). Considering that the world production of phosphogypsum varies between 100 and $280 \mathrm{Mt}$. per year (Parreira et al., 2003; Tayibi et al., 2009), a good approach is to take in consideration phoshogypsum as a possible resource of REE (Kolokolnikov and Kovalev, 2009; Liang et al., 2017).

Sulphate minerals are usually identified in hyperacid crater lakes (Varekamp et al., 2009; Varekamp, 2015; Peiffer et al., 2011; Inguaggiato et al., 2017, 2018), including Kawah Ijen volcano, Indonesia (Delmelle and Bernard, 2015; Van Hinsberg et al., 2017). Higher REE concentrations were recognized worldwide in the hyperacid waters circulating in volcano - hydrothermal systems with respect to the near-neutral $\mathrm{pH}$ waters, boosting the interest to better define the behavior of REE in these peculiar environments (Michard, 1989; Lewis et al., 1998; Wood, 2006; Varekamp et al., 2009; Noack et al., 2014; Varekamp, 2015; Inguaggiato et al., 2015, 2017, 2018).

Hyperacid volcanic lakes are considered as condensers of volcanic gases such as $\mathrm{H}_{2} \mathrm{~S}, \mathrm{SO}_{2}, \mathrm{HCl}$ causing the high acidity of the water. The lake waters do not only trap the gases, but also receive the metals injected by the thermal manifestations; for this reason, hyperacid crater lakes can be considered exotic environments that act as sinks of elements (Varekamp et al., 2000; Henley, 2015). The thermal manifestations, such as fumaroles and thermal springs, are not always visible at the surface because they are sometimes hidden under the water layer. Nevertheless, the physical features of the lake water and its chemical composition reflect the influence of the volcanic-hydrothermal input as well as the changes of the volcanic activity (Rouwet et al., 2014; Varekamp, 2015).

The REE in hyperacid waters from volcano-hydrothermal systems reach concentrations up to $\sim 5$ orders of magnitude higher than seawater (e.g. $\sum$ REE in Poás lake around $2.18 \mathrm{mg} \mathrm{kg}^{-1}$; Inguaggiato et al., 2018). REE mobility in water mainly depends on i) dissolution of primary minerals, ii) presence of anion ligands that can preferentially complex a subgroup of the REE, iii) precipitation of secondary minerals, and iv) dissolution of secondary minerals previously precipitated (Varekamp, 2015). The precipitation of minerals in hyperacid volcanic lakes is related to the physico-chemical conditions of the water, that are mainly function of the volcanic activity changes. Recent investigations focused on the processes that control the mobility of REE in water during the gypsum precipitation, concluding that the REE are mainly incorporated in the gypsum lattice at the Ca site (Dutrizac, 2017; Inguaggiato et al., 2018; Lin et al., 2019).

To the best of our knowledge, only one study quantifies the REE fractionation during gypsum precipitation from natural hyperacid volcanohydrothermal waters, also including the calculation of REE distribution coefficients $\left(K_{D}\right)$ between the gypsum precipitated and the mother brine (Inguaggiato et al., 2018). Volcanic lakes offer the opportunity to carry on experiments using natural solutions in order to study gas water - rock interaction processes. The hyperacid water of Laguna Caliente crater lake at Poás volcano (Costa Rica), was exploited as a natural laboratory (Inguaggiato et al., 2018). High REE concentrations in this lake and in the gypsum precipitated were detected, with values up to $2.18 \mathrm{mg} \mathrm{kg}^{-1}$ in the lake and $33.0 \mathrm{mg} \mathrm{kg}^{-1}$ in the gypsum. Considering that gypsum gained a strategic importance in the investigation of new potential deposits of REE and high REE concentrations were found in hyperacid waters, further studies on the REE concentrations in hyperacid waters and gypsum precipitating in volcanic - hydrothermal systems should be carried out.

In this work the Kawah Ijen hyperacid brine lake water was selected to replicate the experiment carried out by Inguaggiato et al. (2018) to confirm and generalize the geochemical behavior of REE at other volcanic hyperacid lakes and support the idea that they can be considered as possible natural unconventional REE reservoirs. Kawah Ijen lake was chosen because: 1 ) waters are characterized by $\mathrm{pH}$ values $(\sim 0)$ and high concentration of $\mathrm{Al}, \mathrm{Fe}, \mathrm{SO}_{4}$ and $\mathrm{Cl}$, similar to those in Poás lake 2) precipitation of sulphate minerals (gypsum, barite, celestite, Alsulphate) was documented by previous studies (Delmelle and Bernard, 1994; Van Hinsberg et al., 2017) 3) total dissolved salts in Kawah Ijen lake is even higher than Poás lake (Delmelle and Bernard, 1994; Delmelle and Bernard, 2000; Takano et al., 2004; Delmelle and Bernard, 2015; Caudron et al., 2015).

\section{Materials and methods}

\subsection{Sampling and laboratory procedure}

Temperature, $\mathrm{pH}$, as well as most major elements ( $\mathrm{Na}, \mathrm{K}, \mathrm{Ca}, \mathrm{Mg}, \mathrm{SO}_{4}$, $\mathrm{Cl}, \mathrm{F}$ ) are from Caudron et al. (2017). Concentration of other elements 

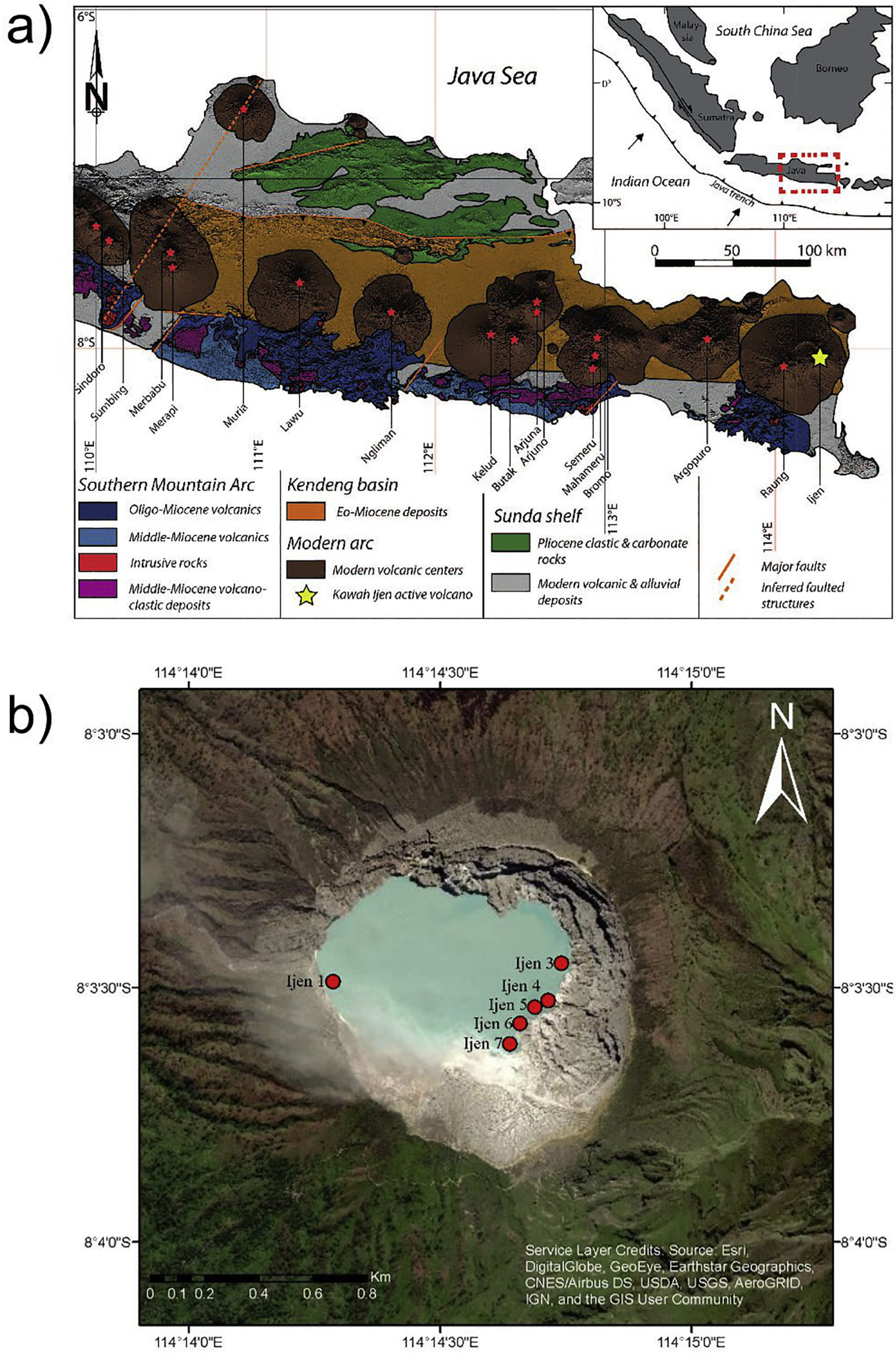

Fig. 1. a) Map showing the tectonic settings of Java island from Caudron et al. (2015) and b) location of samples from the Kawah Ijen crater lake. 
(Al, Fe, Si, Ba, Mn and Sr) were analyzed in duplicate water samples collected during the same campaign as Caudron et al. (2017). In September 2014 , aliquots of $\sim 50 \mathrm{ml}$ were sampled at 6 points of the Kawah Ijen lake (Fig. 1). The waters were initially filtered in the field using $0.45 \mu \mathrm{m}$ filters and stored in polyethylene bottles of $50 \mathrm{ml}$.

A laboratory experiment was set up in order to wait for the natural precipitation of the minerals oversaturated in the lake water. The samples were saved in laboratory at a room temperature of $\sim 25^{\circ} \mathrm{C}$. Chemical analyses were performed on each water sample. After the natural precipitation of the solid phases, each sample was filtered in laboratory using filter with a diameter of $47 \mathrm{~mm}$ and $0.45 \mu \mathrm{m}$ pore size in order to separate the solid phase from the mother brine. XRD analyses were performed to determine the mineral phase.

Subsequently, the solid phase was first stored in plastic vials and dried for $3 \mathrm{~h}$ at $40{ }^{\circ} \mathrm{C}$ then weighed, powdered and dissolved in $1 \mathrm{ml}$ of aqua regia (Ultrex II Ultrapure acids by J.T. Baker) and left in an ultrasonic bath at $50{ }^{\circ} \mathrm{C}$ for $4 \mathrm{~h}$. After that, Millipore water was added up to reach a total volume of $15 \mathrm{ml}$ and left again in an ultrasonic bath at $50{ }^{\circ} \mathrm{C}$ for $4 \mathrm{~h}$. The dissolved minerals were analyzed by ICP-OES and ICP-MS.

\subsection{Analytical procedure}

The density of the water was determined by weighing 5 times $1 \mathrm{ml}$ of water from a pipet previously calibrated with CP224S balance (Sartorius). $\mathrm{Na}, \mathrm{K}, \mathrm{Ca}, \mathrm{Mg}$, $\mathrm{S}$ and $\mathrm{Si}$ in minerals dissolved in aqua regia and $\mathrm{Si}$ in waters after mineral precipitations, were determined by ICP-OES (Jobin Yvon Ultima2) at properly wavelength for each element. The calibration routine was performed on diluted mix of 8 single element stock solutions ( $1000 \mathrm{mg} \mathrm{l}^{-1}$ ) with 8 calibration points prepared daily in $14 \mathrm{ml}$ polyethylene tubes by dilution with $1 \%$ nitric acid. The major elements were determined by the quantitative method using calibration solutions in a different range for each element and calculating the weighted regression curve built with 8 calibration points. The sensitivity variations were monitored by $\mathrm{Y}$ with $1 \mathrm{mg} \mathrm{l}^{-1}$ concentration as internal standard added directly online. The precision of analysis was checked by running 3 replicates and it was always within 5\%. Data accuracy was evaluated analyzing standard reference materials (Spectrapure Standards SW1 and SW2 and NIST 1643e) with error $<10 \%$.

Rare Earth Elements, Al, Fe, Ba, Mn and Sr dissolved in waters after the precipitation of minerals and in minerals were analyzed by Q-ICPMS 7500ce (Agilent). The solutions were diluted up to $\approx 1 \mathrm{~g} \mathrm{l}^{-1}$ according to the initial salinity to avoid nebulizer and cones occlusion. The ICPMS was calibrated with 11 calibration points at different concentration according to the expected concentrations for each element. The solutions of the calibration points were prepared diluting a REE multielement standard solution ( $10 \mathrm{mg} \mathrm{l}^{-1}$ ) and single element standard solutions for $\mathrm{Al}, \mathrm{Fe}, \mathrm{Ba}, \mathrm{Mn}$ and $\mathrm{Sr}$. The sensitivity variation was monitored using ${ }^{103} \mathrm{Rh},{ }^{115} \mathrm{In}$, and ${ }^{185} \mathrm{Re}$ (internal standards) each one at a final concentration of $8 \mu \mathrm{g} \mathrm{l}^{-1}$, added by an appropriate device mixing the internal standard solution with the sample before the nebulizer. A $60 \mathrm{~s}$ rinse using a $0.5 \% \mathrm{HCl}$ and $2 \%$ of $\mathrm{HNO}_{3}$ solution plus a $60 \mathrm{~s}$ rinse using $2 \%$ of $\mathrm{HNO}_{3}$ solution were applied between the analysis of the samples in order to reduce any memory interferences between them. Data accuracy is evaluated analyzing SPS-SW1, SPS-SW2 and SLRS-4 references materials and every single analysis of each element is the average value of 5 replicates. Certified REE concentrations are available for SPSSW1 and SPS-SW2, $500 \pm 10 \mathrm{ng} \mathrm{l}^{-1}$ and $2500 \pm 20 \mathrm{ng} \mathrm{l}^{-1}$, respectively. The REE concentrations of the SLRS-4 are reported in Lawrence et al. (2006). The accuracy of the REE, Al, Fe, Ba, Mn and Sr concentrations calculated with respect to SPSSW1, SPS-SW2 and SLRS-4 are mostly $<10 \%$. The precision of the analysis (average RSD) calculated on five replicates for each element was always $<15 \%$.

High resolution imagines, which provide information about the minerals in the solid phase, as well as the mineral compositions in different points of the crystals surface, were obtained with a JEOL JXA-8230, equipped with five wavelength-dispersion spectrometers (WDS) and operated at $15 \mathrm{kV}$ and $10 \mathrm{nA}$ beam current.

\section{Background information on the Kawah Ijen hydrothermal system}

Kawah Ijen is an active volcano, one of the several volcanoes located in the Pleistocene Ijen caldera ( $15 \mathrm{~km}$ wide), located in the eastern part of Java (Indonesia). It is situated along the volcanic front of the Sunda arc and its genesis is related to the subduction of the Indo-Australian plate beneath the Eurasian plate (Vigouroux et al., 2012). The last volcanic eruption occurred in 1817 causing the total expulsion of the lake (Takano et al., 2004). Since this event, geyser and phreatic activity was reported for the past two centuries (Caudron et al., 2015). The chemical composition of the fresh magmatic deposits mostly varies from basaltic to andesitic, while, the recent volcanic bombs and glass spread to rhyolite. A lava flow located close to the dam is of dacitic composition (Van Hinsberg et al., 2010).

Kawah Ijen hosts the world's largest hyperacid lake in the summit crater and the chemical water homogeneity suggests a mixing due to the thermal convention (Delmelle and Bernard, 1994). Most of the elements dissolved in the lake show relatively stable concentrations, except for $\mathrm{Cr}, \mathrm{Ni}, \mathrm{Ba}, \mathrm{Li}, \mathrm{Be}$, that have higher concentrations close to the lake bottom (Takano et al., 2004).

The seepage of the lake water towards springs located outside the lake area ( $375 \mathrm{~m}$ below the lake level) represent the main sources of the Banyu Pahit, an acidic river that originates on the western flank of the volcano (Palmer et al., 2011). The pH value of the Banyu Pahit increases after the mixing with the neutral waters of Kali Sat and Kali Senggon (Delmelle and Bernard, 2000; Palmer et al., 2011). The high acidity of the lake and Banyu Pahit waters leads to near-complete leaching of elements during water-rock interaction (Van Hinsberg et al., 2010). Anion and cation contents in the lake are controlled by hydrothermal-volcanic inputs and the dissolution of the volcanic rocks (Delmelle and Bernard, 1994; Van Hinsberg et al., 2010). Surface thermal activity consists of crater fumaroles $\left(169^{\circ} \mathrm{C}-450^{\circ} \mathrm{C}\right)$ located on the SE inner crater flank (Delmelle et al., 2000; Gunawan et al., 2016). The identification of sulfur slicks (Takano et al., 2004) and sulfur spherules in the lake (Delmelle and Bernard, 1994), proof the presence of molten sulfur pools at the lake bottom.

Table 1

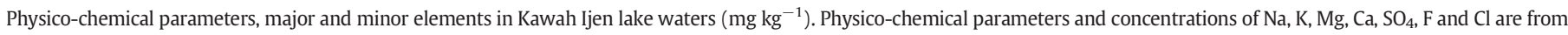
Caudron et al. (2017).

\begin{tabular}{|c|c|c|c|c|c|c|c|c|c|c|c|c|c|c|c|}
\hline Sample & $\mathrm{pH}$ & $\mathrm{T}\left({ }^{\circ} \mathrm{C}\right)$ & $\mathrm{Na}$ & $\mathrm{K}$ & $\mathrm{Ca}$ & $\mathrm{Mg}$ & $\mathrm{Al}$ & $\mathrm{Fe}$ & Mn & $\mathrm{Si}$ & $\mathrm{Sr}$ & $\mathrm{Ba}$ & $\mathrm{Cl}$ & $\mathrm{SO}_{4}$ & $\mathrm{~F}$ \\
\hline Ijen1 & -0.27 & 33.3 & 1124 & 1550 & 648 & 727 & 6288 & 2931 & 50.2 & 45.1 & 21.1 & 0.29 & 20,620 & 66,930 & 1430 \\
\hline Ijen3 & -0.27 & 32.9 & 1089 & 1377 & 646 & 709 & 6496 & 3195 & 52.0 & 44.3 & 21.9 & 0.45 & 20,830 & 67,250 & 1480 \\
\hline Ijen4 & -0.27 & 33.7 & 1029 & 1314 & 617 & 646 & 6502 & 3353 & 52.4 & 41.6 & 22.5 & 0.45 & 20,780 & 66,870 & 1470 \\
\hline Ijen 5 & -0.27 & 32.2 & 1048 & 1133 & 655 & 669 & 6117 & 2952 & 50.0 & 40.1 & 20.9 & 0.27 & 24,310 & 70,370 & 2700 \\
\hline Ijen6 & -0.28 & 33.4 & 1083 & 1124 & 620 & 670 & 6616 & 3291 & 54.5 & 46.4 & 23.1 & 0.32 & 24,510 & 70,250 & 2460 \\
\hline Ijen7 & -0.27 & 33.8 & 1075 & 1156 & 632 & 677 & 5926 & 3126 & 49.1 & 44.0 & 21.3 & 0.36 & 22,310 & 69,890 & 1870 \\
\hline
\end{tabular}




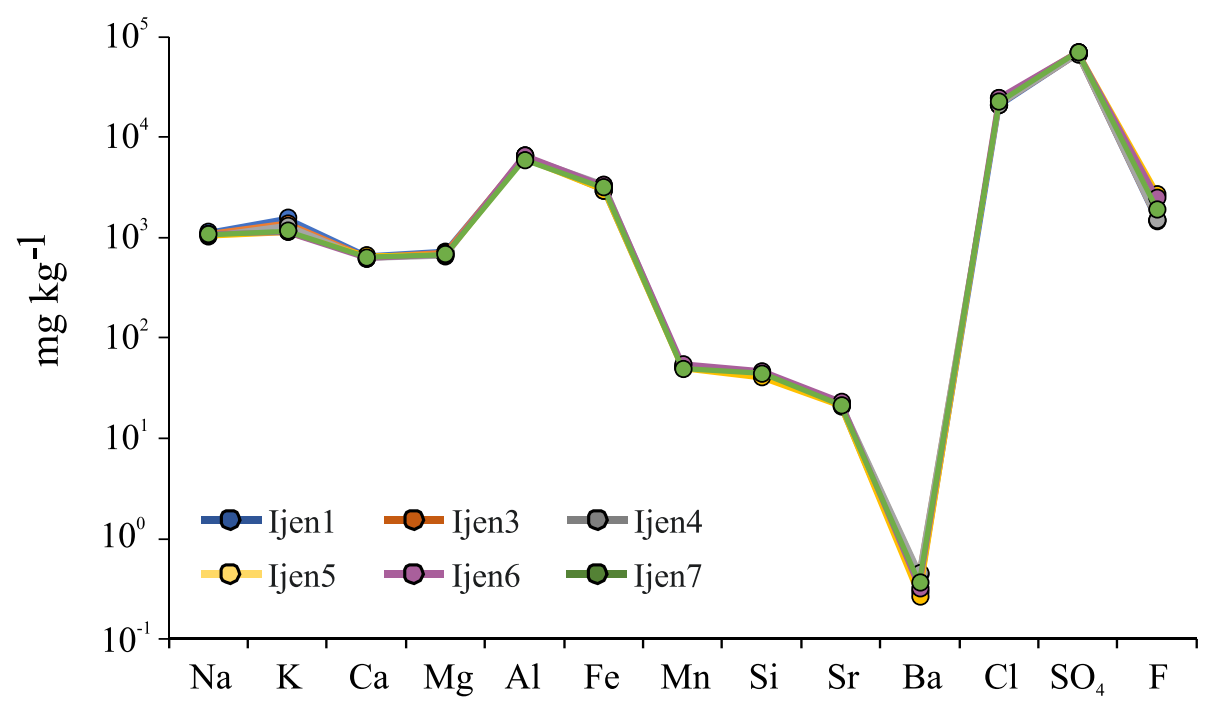

Fig. 2. Major elements dissolved in water $\left(\mathrm{mg} \mathrm{kg}^{-1}\right)$.

\section{Results}

\subsection{Physico-chemical parameters and major elements in water}

In September 2014, lake waters were collected close to the shoreline at $15 \mathrm{~cm}$ below the surface of the lake, 5 samples in the south-eastern sector and 1 sample in the western sector (close to the dam; Fig. 1). Major elements, $\mathrm{pH}$ and temperature data are from Caudron et al. (2017), for corresponding sample numbers, while Al, Fe, Mn, Si, Sr and Ba were analyzed in this study (Table 1). Sampling temperature and $\mathrm{pH}$ values are quite constant in all the sampled waters, $\sim 33.3{ }^{\circ} \mathrm{C}$ and -0.27 respectively (Table 1 ).

Table 2

Major oxides (wt.\%) of the minerals precipitated from Kawah Ijen lake water during the experiment, determined using the electron microprobe.

\begin{tabular}{lllrrrrrrr}
\hline Sample & $\mathrm{Na} 2 \mathrm{O}$ & $\mathrm{SrO}$ & $\mathrm{SiO}_{2}$ & $\mathrm{Al}_{2} \mathrm{O}_{3}$ & $\mathrm{CaO}$ & $\mathrm{K}_{2} \mathrm{O}$ & \multicolumn{1}{c}{$\mathrm{FeO}$} & $\mathrm{SO}_{3}$ & \multicolumn{1}{c}{$\mathrm{BaO}$} \\
\hline Ijen1_001 & 0.01 & 0.06 & 0.03 & 0.04 & 38.39 & 0.02 & 0.03 & 57.39 & 0.00 \\
Ijen3_001 & 0.01 & 0.02 & 0.45 & 19.30 & 18.94 & 1.60 & 11.39 & 57.72 & 0.02 \\
Ijen3_002 & 0.55 & 0.00 & 0.19 & 17.84 & 0.92 & 0.96 & 0.71 & 49.15 & 0.01 \\
Ijen7_001 & 0.15 & 9.51 & 12.33 & 0.29 & 4.24 & 0.91 & 0.54 & 29.61 & 14.77 \\
\hline
\end{tabular}

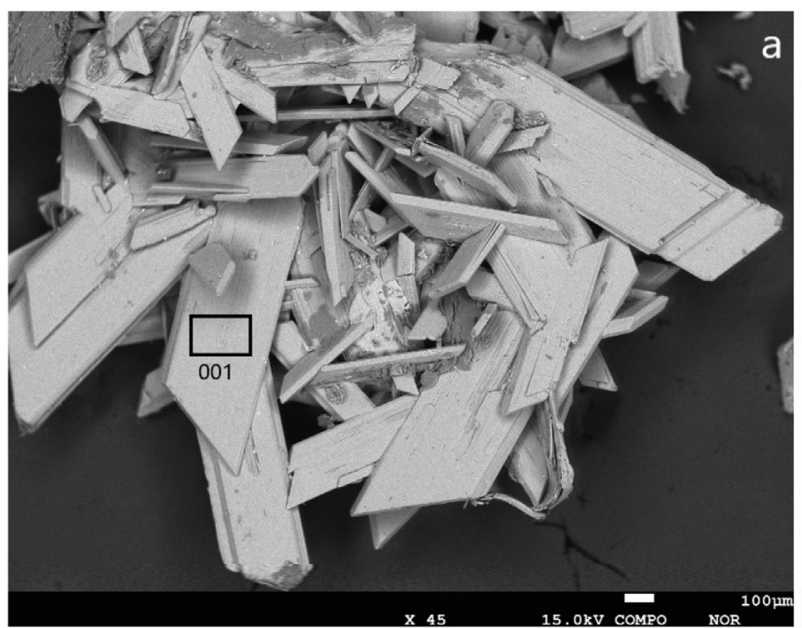

The cation composition is dominated by Al with concentrations up to $6616 \mathrm{mg} \mathrm{kg}^{-1}$ and Fe that reaches concentration of $3353 \mathrm{mg} \mathrm{kg}^{-1}$. $\mathrm{Na}$ and $\mathrm{K}$ concentrations range from 1029 to $1124 \mathrm{mg} \mathrm{kg}^{-1}$ and from 1124 to $1550 \mathrm{mg} \mathrm{kg}^{-1}$, respectively. $\mathrm{Mg}$ and Ca show variations with values between 617 and $727 \mathrm{mg} \mathrm{kg}^{-1}$. Mn, $\mathrm{Si}$, Sr and Ba have concentration ranging from 49.1 to $54.5 \mathrm{mg} \mathrm{kg}^{-1}$, from 40.1 to $46.4 \mathrm{mg} \mathrm{kg}^{-1}$, from 20.9 to $23.1 \mathrm{mg} \mathrm{kg}^{-1}$ and from 0.29 to $0.45 \mathrm{mg} \mathrm{kg}^{-1}$, respectively. The anion composition is dominated by $\mathrm{SO}_{4}$ and $\mathrm{Cl}$ with $\mathrm{SO}_{4} / \mathrm{Cl}$ weight ratios ranging from 2.9 to $3.2 . \mathrm{SO}_{4}$ and $\mathrm{Cl}$ concentrations range from 66,870 to $70,370 \mathrm{mg} \mathrm{kg}^{-1}$ and from 20,620 to $24,510 \mathrm{mg} \mathrm{kg}^{-1}$, respectively. F concentrations are between 1430 and $2700 \mathrm{mg} \mathrm{kg}^{-1}$.

The semi-logarithmic binary graph shows that major and minor elements dissolved in the different water samples have similar concentrations (Fig. 2).

\subsection{Mineralogy}

The XRD results show that the mineral phase precipitating from the lake water is mainly composed of gypsum crystals. Only the samples Ijen1, Ijen3, Ijen 4 and Ijen7 are characterized by low percentages of anhydrite ( $5 \%)$. However, microprobe analyses on selected minerals show that not only gypsum but also others sulphate minerals precipitated on the surface of gypsum minerals. In Table 2 the concentration of each major element is expressed as weight per cent (wt.\%) of the

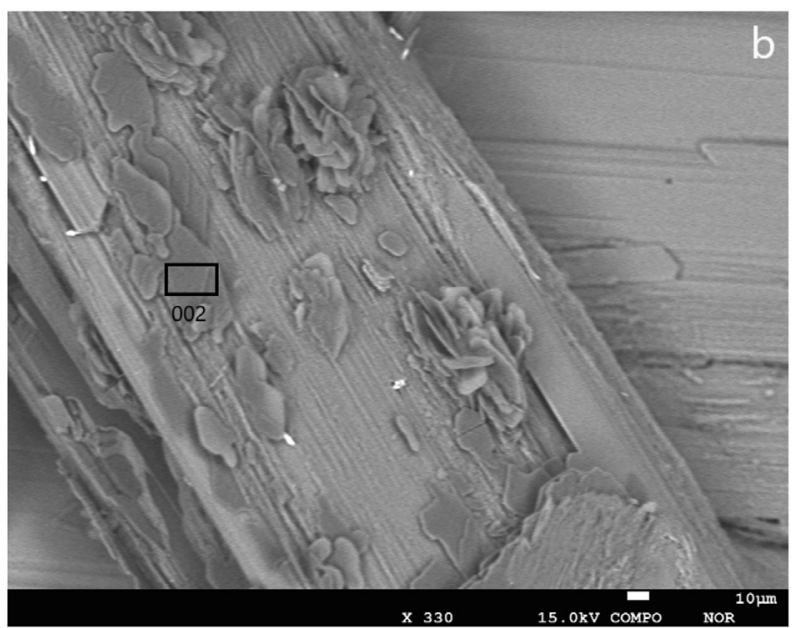

Fig. 3. a) Gypsum minerals identified in sample Ijen1 (Ijen1_001) b) Al-sulphate minerals identified in sample Ijen3 (Ijen3_002). 
corresponding oxide. The solid phases identified are: 1) gypsum (Fig. 3a), 2) Al-sulphate (Fig. 3b), 3) Fe, K-sulphate (Fig. 4a) and 4) Ba, Sr-sulphate (Fig. 4b). According to the relative abundance of the oxides identified and reported in Table 2, the possible sulphate minerals are: 1) jarosite $\left.\left(\mathrm{K}, \mathrm{Fe}_{3}\left(\mathrm{SO}_{4}\right)_{2}(\mathrm{OH})_{6}\right), 2\right)$ alunogen $\left(\mathrm{Al}_{2}\left(\mathrm{SO}_{4}\right)_{3} \cdot 17\left(\mathrm{H}_{2} \mathrm{O}\right)\right)$,
3) barite $\left(\mathrm{BaSO}_{4}\right)$ and 4$)$ celestite $\left(\mathrm{SrSO}_{4}\right)$. Sr-sulphate could be also interpreted as a Sr-bearing barite, similarly to the results obtained by Delmelle and Bernard (1994) which found $\mathrm{Pb}-\mathrm{Sr}$ enriched barite in the suspended solids. Al-sulphate appears like a thin coating overlying the surface of the gypsum crystals. In some samples, it crystalizes in a
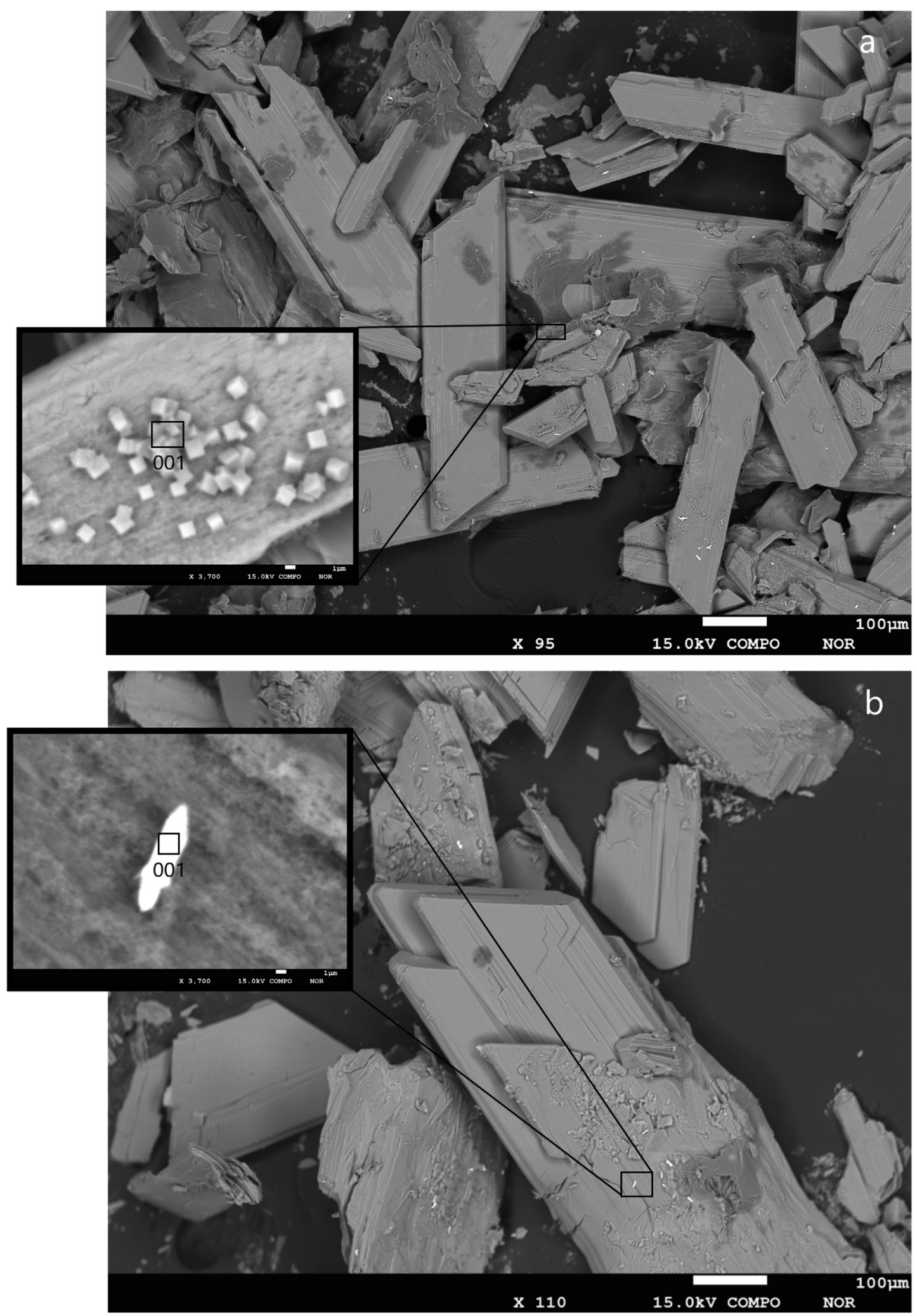

Fig. 4. a) Fe-, K-sulphate minerals (possible jarosite) in sample Ijen3 (Ijen3_001) and b) Ba, Sr - sulphate in the sample Ijen7 (Ijen7_001). 
Table 3

Major oxides (wt.\%) of the solid phase precipitated from Kawah Ijen lake water during the experiment, determined using the ICP-OES.

\begin{tabular}{lllllllllll}
\hline Sample & $\mathrm{Na}_{2} \mathrm{O}$ & $\mathrm{K}_{2} \mathrm{O}$ & $\mathrm{MgO}$ & $\mathrm{CaO}$ & $\mathrm{SiO}_{2}$ & $\mathrm{SO}_{3}$ & $\mathrm{Al}_{2} \mathrm{O}_{3}$ & $\mathrm{Fe}_{2} \mathrm{O}_{3}$ & $\mathrm{BaO}$ & $\mathrm{SrO}$ \\
\hline Ijen 1 & 1.76 & 0.46 & 0.21 & 35.50 & 1.05 & 52.99 & 0.59 & 0.25 & 0.13 & 0.82 \\
Ijen 3 & 2.27 & 1.35 & 0.43 & 35.06 & 0.78 & 50.88 & 1.22 & 0.51 & 0.23 & 0.80 \\
Ijen 4 & 2.06 & 0.77 & 0.40 & 33.51 & 0.75 & 48.73 & 1.04 & 0.56 & 0.23 & 0.95 \\
Ijen 5 & 1.87 & 1.22 & 0.28 & 35.78 & 0.87 & 50.69 & 0.82 & 0.29 & 0.11 & 0.68 \\
Ijen 6 & 1.50 & 1.09 & 0.18 & 33.57 & 1.18 & 46.52 & 0.63 & 0.21 & 0.14 & 0.76 \\
Ijen 7 & 1.95 & 1.67 & 0.21 & 34.99 & 1.08 & 49.97 & 0.90 & 0.36 & 0.18 & 0.89 \\
\hline
\end{tabular}

rosette growth pattern (as shown in Fig. 3b). The qualitative volumetric proportion of Al-sulphate minerals is higher in the sample Ijen3 compared to the other samples.

The solid phase determined via XRD and electron microprobe was also wholly dissolved and analyzed by ICP-OES (Table 3 ). The analyses are expressed as weight \% (wt.\%) of element oxides (Table 3). The main components of the solid phase are $\mathrm{CaO}$ (33.5-35.8 wt.\%) and $\mathrm{SO}_{3}$ (46.5-53.0 wt.\%), followed by $\mathrm{Na}_{2} \mathrm{O}$ (1.5-2.3 wt.\%). $\mathrm{SiO}_{2}, \mathrm{Al}_{2} \mathrm{O}_{3}, \mathrm{Fe}_{2} \mathrm{O}_{3}$ and $\mathrm{SrO}$ have similar concentrations (0.8-1.2 wt.\%, 0.6-1.22 wt.\%, $0.2-0.6$ wt.\% and $0.7-1.0$ wt.\% respectively). $\mathrm{BaO}$ and $\mathrm{MgO}$ are characterized by lower concentrations with values $<0.4 \mathrm{wt}$.\%.

The major element composition of the solid phase is consistent with the result obtained from XRD and electron microprobe analysis. The low amount of the Fe-, K-, Al-, Sr-, Ba-sulphate minerals, confirms that solid phases precipitated from the lake water solution appear to be mostly gypsum with low amounts of other sulphate minerals.

\subsection{REE in waters and minerals precipitated}

The lake water shows high concentrations in total REE ranging from 5.86 to $6.52 \mathrm{mg} \mathrm{kg}^{-1}$ (Table 4) with the lowest value in the western sector of the lake (Ijen1) and the highest concentration in the eastern one
(Ijen6). The REE were subdivided in two groups: 1) LREE from La to Tb and 2) HREE from Dy to Lu, including Y.

The REE were normalized to the average composition of REE in the local rocks, unaltered fresh magmatic deposits, ranging in bulk composition from basalt/andesite to dacite (Van Hinsberg et al., 2010). The normalization to the average magmatic local rock allows evaluating the water-rock interaction in the Kawah Ijen volcanic - hydrothermal system. The REE dissolved in water normalized to the local rock show flat patterns in the lake waters (Fig. 5).

The total concentration of REE in minerals precipitated from the lake water during the experiment in laboratory at room temperature $\left(\sim 25^{\circ} \mathrm{C}\right)$ is higher with respect to that in the water, with concentrations ranging from 59.53 to $78.64 \mathrm{mg} \mathrm{kg}^{-1}$ (Table 5). On the contrary, the patterns of REE in minerals precipitated from the lake waters normalized to the local rock show LREE enrichment with respect to the HREE (Fig. 6). REE analyzed in gypsum precipitated on the terrace of the seepage area and in Al-sulphate mineral found in the riverbed of Banyu Pahit by Van Hinsberg et al. (2017) were reported for comparison. REE in gypsum from the terrace (KV07-505 in Fig. 6) show the same pattern recognized in the gypsum precipitated in laboratory. On the contrary, REE in Alsulphate mineral (KV07-701 in Fig. 6) have a different pattern with REE increasing from La to Lu.

\section{Discussion}

\subsection{Fractionation of major elements by mineral precipitation in Kawah Ijen lake}

Our results on the identification of minerals precipitating during the experiment coincide with the minerals recognized by previous authors in Kawah Ijen (Delmelle and Bernard, 1994; Van Hinsberg et al., 2017). The solid phase naturally precipitated during the experiment carried

Table 4

Rare earth elements dissolved in Kawah Ijen lake waters $\left(\mu \mathrm{g} \mathrm{kg}^{-1}\right)$.

\begin{tabular}{|c|c|c|c|c|c|c|c|c|c|c|c|c|c|c|c|c|}
\hline Sample & La & $\mathrm{Ce}$ & $\operatorname{Pr}$ & $\mathrm{Nd}$ & Sm & $\mathrm{Eu}$ & Gd & $\mathrm{Tb}$ & Dy & $\mathrm{Y}$ & Ho & $\mathrm{Er}$ & $\mathrm{Tm}$ & $\mathrm{Yb}$ & Lu & $\Sigma \mathrm{REE}$ \\
\hline Ijen1 & 841.5 & 1799.7 & 226.8 & 917.3 & 201.7 & 54.2 & 197.5 & 29.6 & 196.0 & 1109.4 & 34.4 & 101.6 & 14.5 & 113.9 & 17.4 & 5855.6 \\
\hline Ijen3 & 884.6 & 1880.8 & 238.4 & 965.3 & 211.3 & 56.0 & 205.3 & 30.9 & 209.2 & 1145.7 & 35.9 & 106.2 & 15.2 & 119.4 & 18.1 & 6122.5 \\
\hline Ijen4 & 903.8 & 1928.5 & 243.5 & 991.7 & 219.1 & 58.6 & 210.6 & 31.2 & 208.3 & 1157.9 & 36.3 & 108.4 & 15.8 & 122.3 & 18.1 & 6253.9 \\
\hline Ijen5 & 856.6 & 1831.2 & 232.5 & 945.7 & 210.1 & 54.6 & 200.0 & 29.7 & 199.1 & 1102.6 & 34.9 & 105.0 & 14.5 & 116.2 & 17.8 & 5950.6 \\
\hline Ijen6 & 937.7 & 2001.1 & 255.1 & 1030.9 & 229.9 & 60.1 & 219.5 & 33.2 & 220.2 & 1211.8 & 38.3 & 113.7 & 16.2 & 129.2 & 19.4 & 6516.1 \\
\hline Ijen7 & 851.3 & 1829.6 & 232.8 & 950.0 & 208.1 & 55.6 & 202.8 & 30.0 & 197.8 & 1095.5 & 34.6 & 103.4 & 14.6 & 116.6 & 17.2 & 5939.8 \\
\hline
\end{tabular}

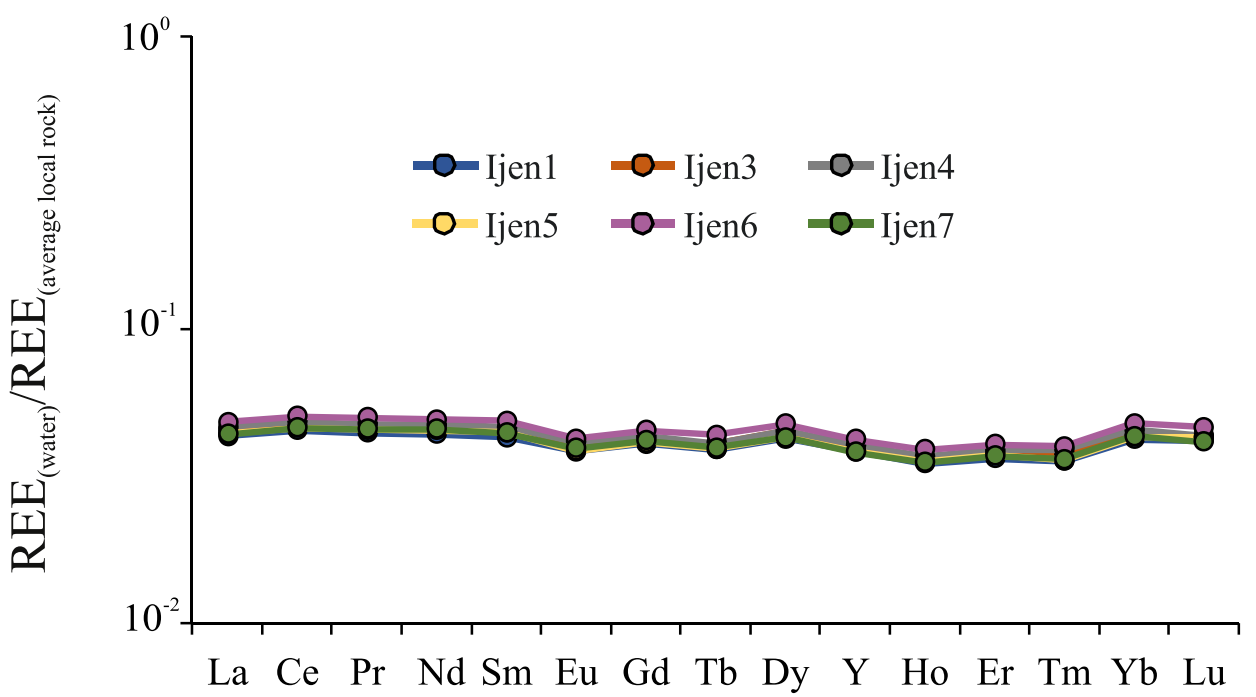

Fig. 5. REE in Kawah Ijen lake waters normalized to the average magmatic local rock. 
Table 5

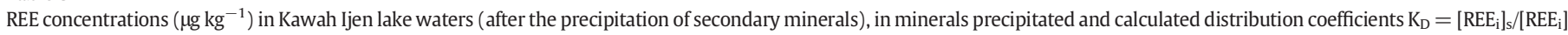
aq.

\begin{tabular}{|c|c|c|c|c|c|c|c|c|c|c|c|c|c|c|c|c|}
\hline Sample & La & $\mathrm{Ce}$ & $\operatorname{Pr}$ & $\mathrm{Nd}$ & $\mathrm{Sm}$ & Eu & Gd & $\mathrm{Tb}$ & Dy & $\mathrm{Y}$ & Ho & Er & $\mathrm{Tm}$ & $\mathrm{Yb}$ & Lu & $\Sigma \mathrm{REE}$ \\
\hline \multicolumn{17}{|c|}{ Rare earth elements in water after precipitation of minerals $\left(\mu \mathrm{gg}^{-1}\right)$} \\
\hline Ijen 1 & 820.9 & 1746.5 & 219.7 & 889.0 & 196.9 & 53.3 & 194.8 & 29.3 & 194.9 & 1105.8 & 34.2 & 101.2 & 14.4 & 113.7 & 17.4 & 5731.9 \\
\hline Ijen 3 & 861.9 & 1832.2 & 232.5 & 942.7 & 207.5 & 55.2 & 202.9 & 30.6 & 208.1 & 1142.0 & 35.7 & 105.8 & 15.2 & 119.2 & 18.1 & 6009.7 \\
\hline Ijen 4 & 877.6 & 1867.5 & 235.6 & 960.5 & 214.0 & 57.6 & 207.5 & 30.9 & 206.9 & 1153.4 & 36.1 & 107.9 & 15.8 & 122.0 & 18.0 & 6111.2 \\
\hline Ijen 5 & 839.7 & 1784.1 & 226.1 & 919.2 & 205.7 & 53.8 & 197.4 & 29.5 & 198.1 & 1099.5 & 34.7 & 104.6 & 14.5 & 116.0 & 17.8 & 5840.5 \\
\hline Ijen 6 & 916.8 & 1947.7 & 248.1 & 1002.9 & 225.1 & 59.1 & 216.6 & 32.9 & 219.0 & 1208.2 & 38.1 & 113.3 & 16.2 & 128.9 & 19.3 & 6392.3 \\
\hline Ijen 7 & 828.3 & 1774.8 & 225.9 & 922.7 & 203.5 & 54.6 & 200.0 & 29.7 & 196.5 & 1091.5 & 34.4 & 103.0 & 14.6 & 116.3 & 17.2 & 5813.1 \\
\hline \multicolumn{17}{|c|}{ Rare earth elements in minerals precipitated (mainly gypsum) $\left(\mu \mathrm{g} \mathrm{kg}^{-1}\right)$} \\
\hline Ijen 1 & $10,891.9$ & $28,111.5$ & 3751.2 & $14,958.6$ & 2512.6 & 497.4 & 1477.5 & 150.1 & 631.9 & 1868.5 & 86.4 & 229.9 & 19.7 & 122.7 & 15.6 & $65,325.4$ \\
\hline Ijen 3 & $12,309.2$ & $26,351.3$ & 3209.9 & $12,292.1$ & 2068.1 & 447.4 & 1299.1 & 135.8 & 622.8 & 2010.2 & 86.6 & 229.1 & 20.9 & 139.3 & 17.7 & $61,239.4$ \\
\hline Ijen 4 & $14,432.9$ & $33,571.2$ & 4327.2 & $17,172.5$ & 2808.2 & 598.1 & 1714.2 & 175.0 & 781.4 & 2459.2 & 102.8 & 277.1 & 25.9 & 174.8 & 21.6 & $78,642.3$ \\
\hline Ijen 5 & 9130.1 & $25,471.0$ & 3460.2 & $14,311.1$ & 2409.3 & 473.0 & 1415.0 & 145.8 & 576.4 & 1704.6 & 80.6 & 215.2 & 19.1 & 106.9 & 15.5 & $59,533.8$ \\
\hline Ijen 6 & $10,622.7$ & $27,068.4$ & 3522.7 & $14,240.3$ & 2399.8 & 499.8 & 1462.0 & 148.4 & 607.4 & 1815.2 & 82.4 & 215.3 & 18.7 & 114.7 & 14.4 & $62,832.1$ \\
\hline Ijen 7 & $12,396.8$ & $29,438.6$ & 3699.7 & $14,679.8$ & 2460.7 & 531.0 & 1490.4 & 162.3 & 686.7 & 2108.2 & 90.3 & 228.0 & 21.6 & 127.9 & 17.2 & $68,139.2$ \\
\hline \multicolumn{17}{|c|}{ KD (REE in minerals precipitated/REE in mother brine) } \\
\hline Ijen 1 & 13.3 & 16.1 & 17.1 & 16.8 & 12.8 & 9.3 & 7.6 & 5.1 & 3.2 & 1.7 & 2.5 & 2.3 & 1.4 & 1.1 & 0.9 & \\
\hline Ijen 3 & 14.3 & 14.4 & 13.8 & 13.0 & 10.0 & 8.1 & 6.4 & 4.4 & 3.0 & 1.8 & 2.4 & 2.2 & 1.4 & 1.2 & 1.0 & \\
\hline Ijen 4 & 16.4 & 18.0 & 18.4 & 17.9 & 13.1 & 10.4 & 8.3 & 5.7 & 3.8 & 2.1 & 2.8 & 2.6 & 1.6 & 1.4 & 1.2 & \\
\hline Ijen 5 & 10.9 & 14.3 & 15.3 & 15.6 & 11.7 & 8.8 & 7.2 & 4.9 & 2.9 & 1.6 & 2.3 & 2.1 & 1.3 & 0.9 & 0.9 & \\
\hline Ijen 6 & 11.6 & 13.9 & 14.2 & 14.2 & 10.7 & 8.5 & 6.7 & 4.5 & 2.8 & 1.5 & 2.2 & 1.9 & 1.2 & 0.9 & 0.7 & \\
\hline Ijen 7 & 15.0 & 16.6 & 16.4 & 15.9 & 12.1 & 9.7 & 7.5 & 5.5 & 3.5 & 1.9 & 2.6 & 2.2 & 1.5 & 1.1 & 1.0 & \\
\hline
\end{tabular}

out in the laboratory is mainly gypsum as identified by XRD analysis and in agreement with the analysis of the solid phase chemical composition (Table 2, Table 3). Moreover, the overgrowth of other minerals on the surface of gypsum crystals, mainly composed by $\mathrm{Fe}_{2} \mathrm{O}_{3}, \mathrm{Al}_{2} \mathrm{O}_{3}, \mathrm{BaO}$ and $\mathrm{SrO}$, each one with high $\mathrm{SO}_{3}$ concentrations, allow us to suggest the possible precipitation of other sulphate minerals, such as Al-sulphate, jarosite, barite and celestite. Delmelle and Bernard (1994) estimated the saturation indexes of minerals via thermodynamic calculation, investigated the nature of the suspended solids and of the sediments in the lake, the latter collected at depths of 20-35 m and. Amorphous silica, $\alpha$ - christobalite, quartz (minor amounts), gypsum, barite, celestite, anatase and rare native $S$ particles were recognized in the suspended solids. Most of these phases were also identified by XRD analysis in lake sediments. Van Hinsberg et al. (2017) identified gypsum precipitated from the uppermost seepage outlets, barite and Alsulphate on the altered rocks close to the seepage springs as well as in the riverbed. In addition, yellow Al-sulphate minerals were recognized on the riverbank (Banyu Pahit river).

The isosol diagram was used in order to compare the major elements dissolved in lake water with respect to the major elements composition in the average volcanic local rock (Fig. 7; Taran et al., 2008; Colvin et al., 2013; Varekamp, 2015; Inguaggiato et al., 2017). This graph is a useful tool to evaluate if the water chemical composition is the result of congruent dissolution of the rock or it is affected by possible precipitation/dissolution of minerals that can deplete or enrich given elements. The average chemical composition of the major elements in the unaltered fresh magmatic deposits ranging in bulk composition from basalt/andesite to dacite (Van Hinsberg et al., 2010), was reported in the isosol plot. The chemical

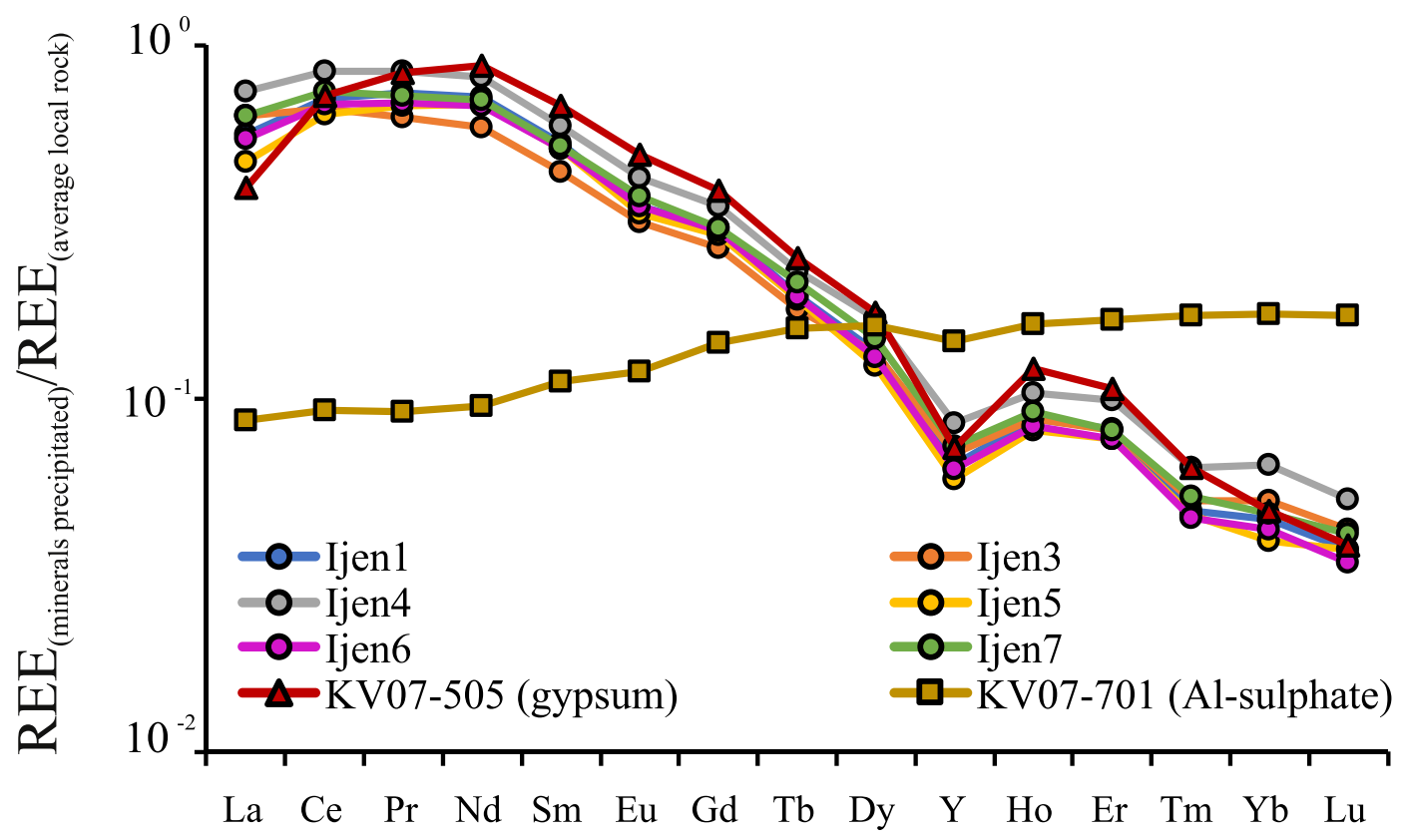

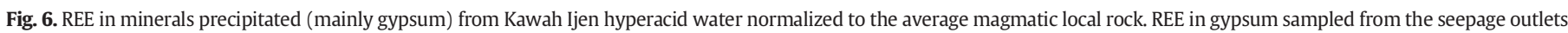
and Al-sulphate from the Banyu Pahit river bank are reported for comparison (samples KV07-505 and KV07-701, respectively; Van Hinsberg et al., 2017). 


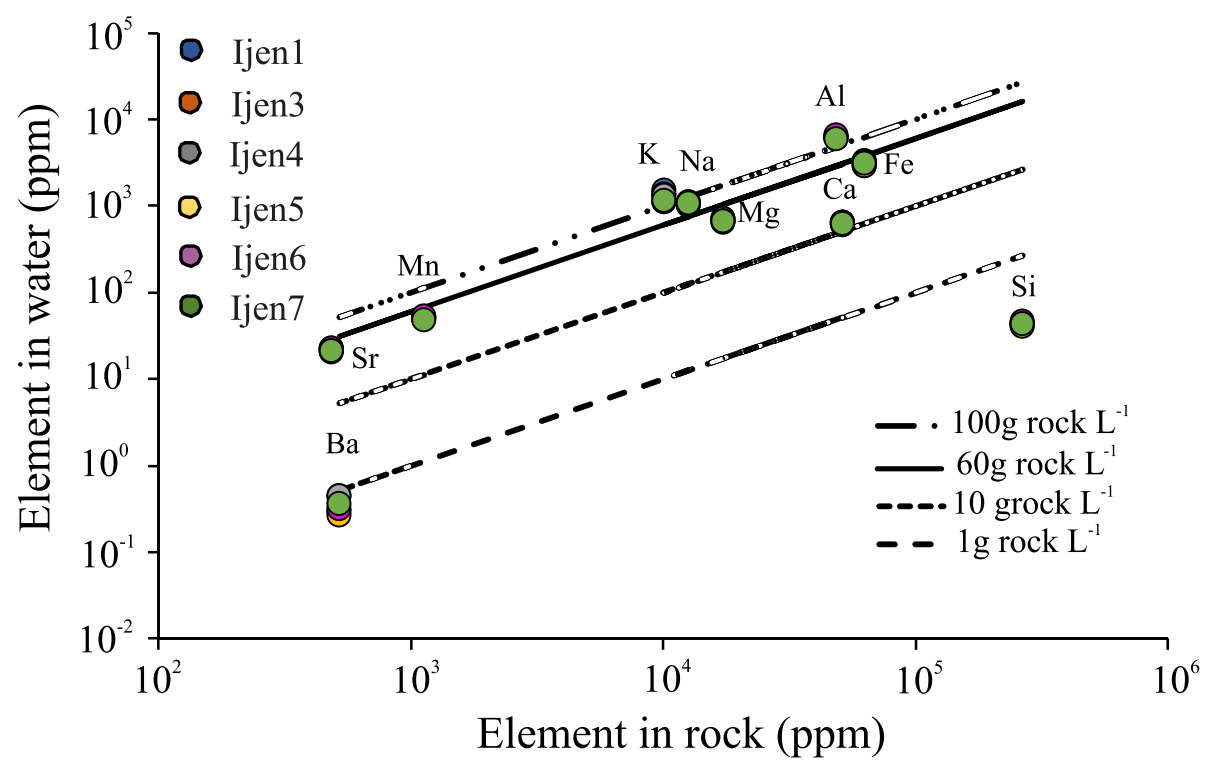

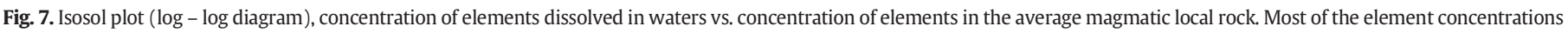
are between the lines representing the congruent dissolution of 60 and $100 \mathrm{~g}$ of rock per liter. Si, Ba and Ca show depletions.

composition of the major elements in lake water is from Caudron et al. (2017) while other elements plotted (Al, Fe, Si, Mn, Sr and Ba) are from this work (Fig. 7). The lines plotted in the graph represent the grams of the average magmatic local rock dissolved per liter of water, assuming that a congruent dissolution occurs. Most of the elements fall between the lines representing the congruent dissolution between $\sim 60$ and $\sim 100 \mathrm{~g}$ of rock per liter of water (Fig. 7). Similarly, the thermodynamic model presented by Delmelle and Bernard (1994) indicate that $60 \mathrm{~g}$ of andesite dissolution per liter of water can produce the cation concentrations of Ijen lake. On the contrary $\mathrm{Ca}, \mathrm{Ba}$ and $\mathrm{Si}$ are the elements that most negatively deviate from the line representing the congruent dissolution of $\sim 60 \mathrm{~g}$ of rock per liter of water (Fig. 7). The Ca, Ba and Si depletions in lake water are due to the precipitation of gypsum, barite and $\mathrm{SiO}_{2}$, minerals identified from this work and previous studies (Delmelle and Bernard, 1994; Van Hinsberg et al., 2017).

\subsection{Fractionation of REE by mineral precipitation in Kawah Ijen lake}

REE concentration in the Kawah Ijen water lake is high, up to $6.52 \mathrm{mg} \mathrm{kg}^{-1}$, significantly higher (up to 6 orders of magnitude) with respect to the concentration in other continental and marine waters (Noack et al., 2014). Moreover it is interesting to find that REE concentrations in
Kawah Ijen lake represent one of the highest values already recognized in others hyperacid waters in different volcano hydrothermal systems worldwide (Michard, 1989; Kikawada et al., 1993; Lewis et al., 1998; Varekamp et al., 2009; Peiffer et al., 2011; Kalacheva et al., 2015; Varekamp, 2015; Woitischek et al., 2017; Inguaggiato et al., 2015, 2017, 2018).

In this study we carried out an experiment exploiting the water of Kawah Ijen lake as natural laboratory, as presented in detail in section 2. It basically consists in waiting (at temperature of $\sim 25^{\circ} \mathrm{C}$ ) for the natural precipitation of the minerals in the lake water. The contents of REE in the lake mainly depend on the interaction of the hyperacid water with the primary rocks. It is also known that cations in lake water are also supplied by the water interaction with the rocks falling in the lake (Van Hinsberg et al., 2010). If the precipitation of secondary minerals occurs, the immobilization of REE due to the scavenging in secondary minerals is function of the REE $K_{D}$ of each element in each specific mineral precipitating.

The $K_{D}$ of REE between the precipitated minerals ( $100 \%$ gypsum) during the experiment from the lake water and the lake water was calculated in this study using the following formula:

$\mathrm{K}_{\mathrm{D}}=\left[\mathrm{REE}_{\mathrm{i}}\right]_{\mathrm{s}} /\left[\mathrm{REE}_{\mathrm{i}}\right]_{\mathrm{aq}}$

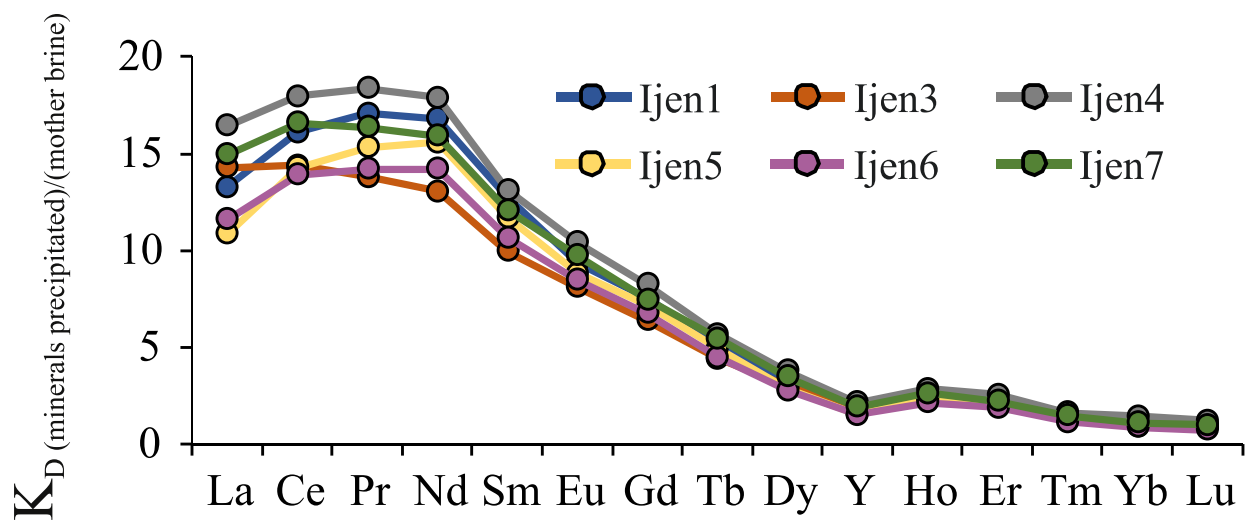

Fig. 8. Distribution coefficient of REE ( $\mathrm{K}_{\mathrm{D}}$ ) calculated between minerals precipitated (mainly gypsum) and the mother brine (hyperacid water of Kawah Ijen). 

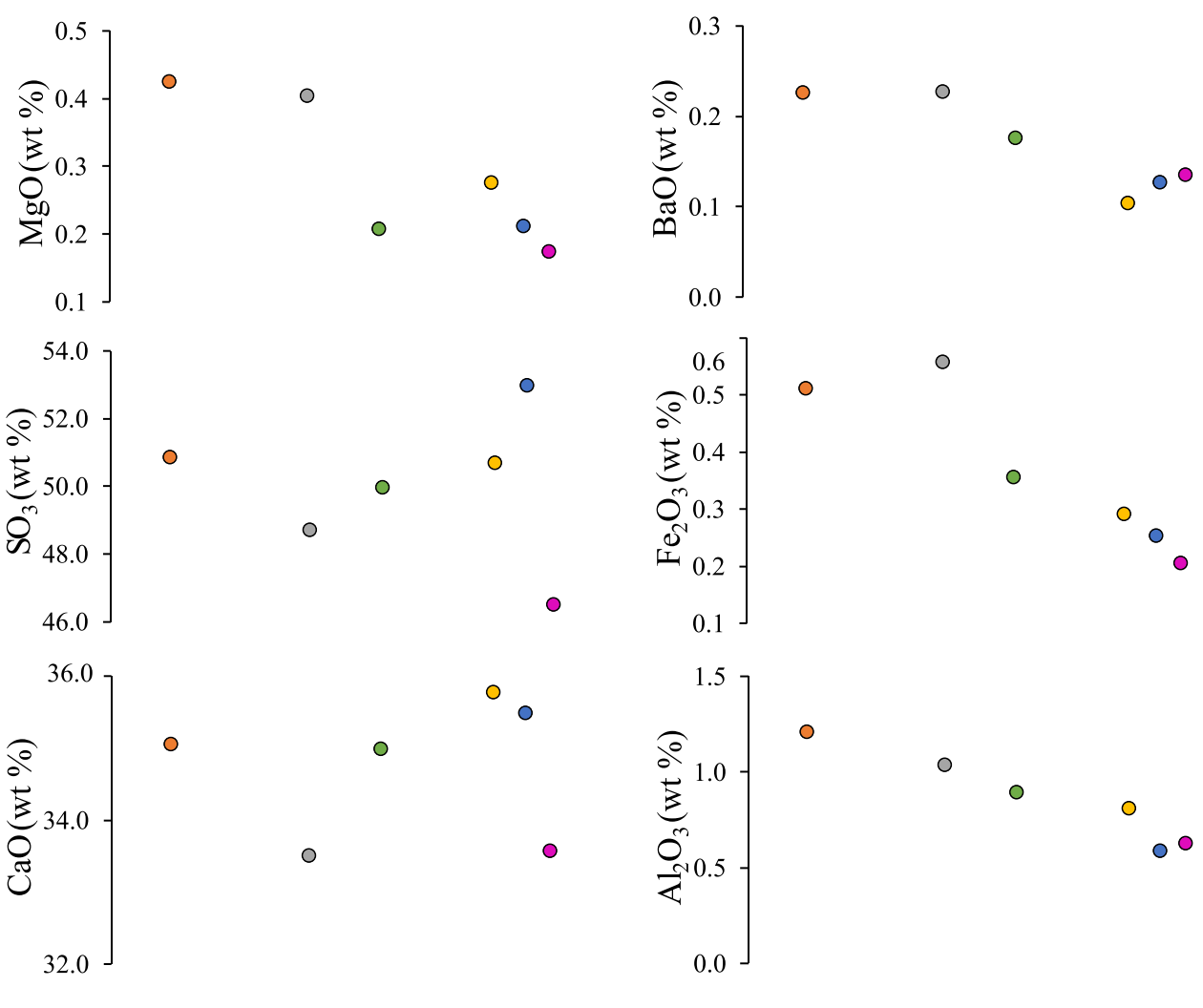

○
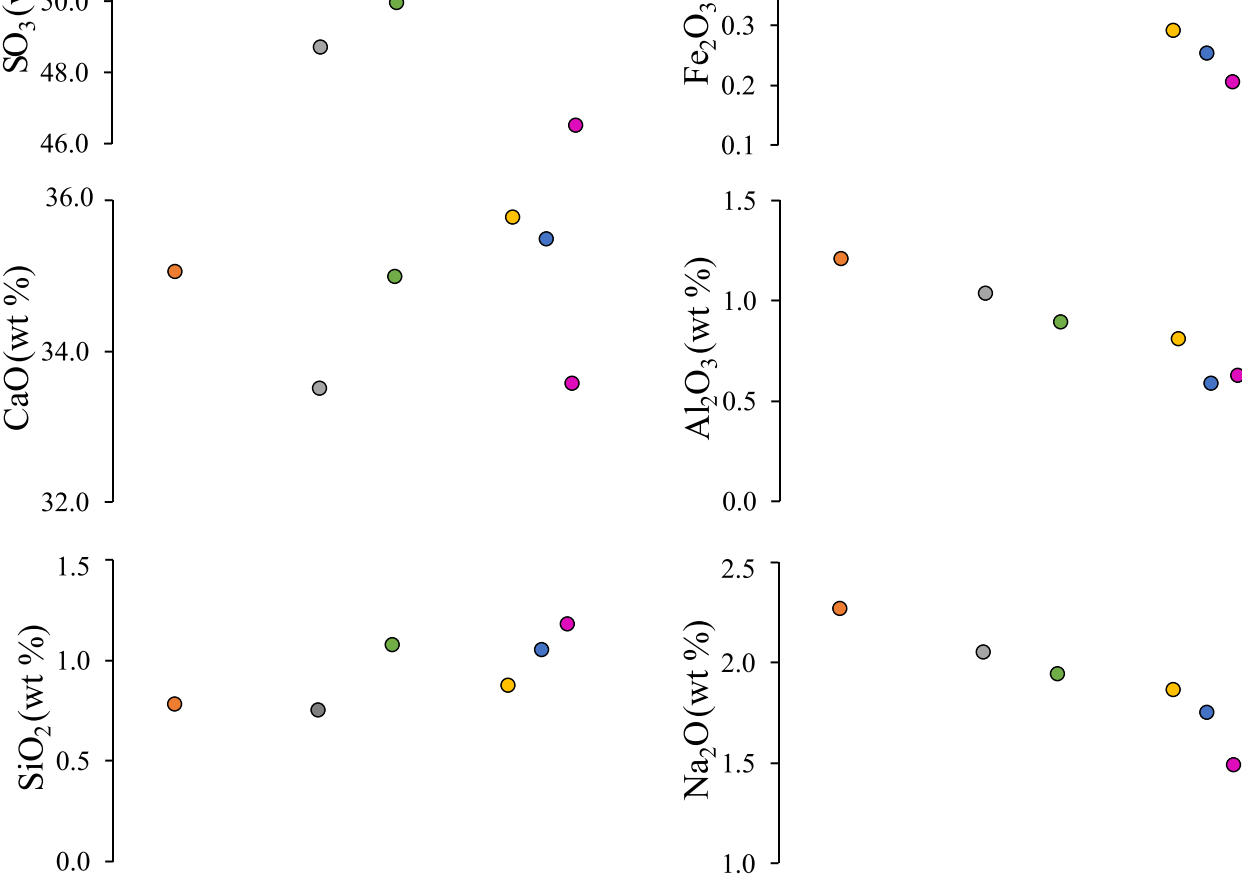

○
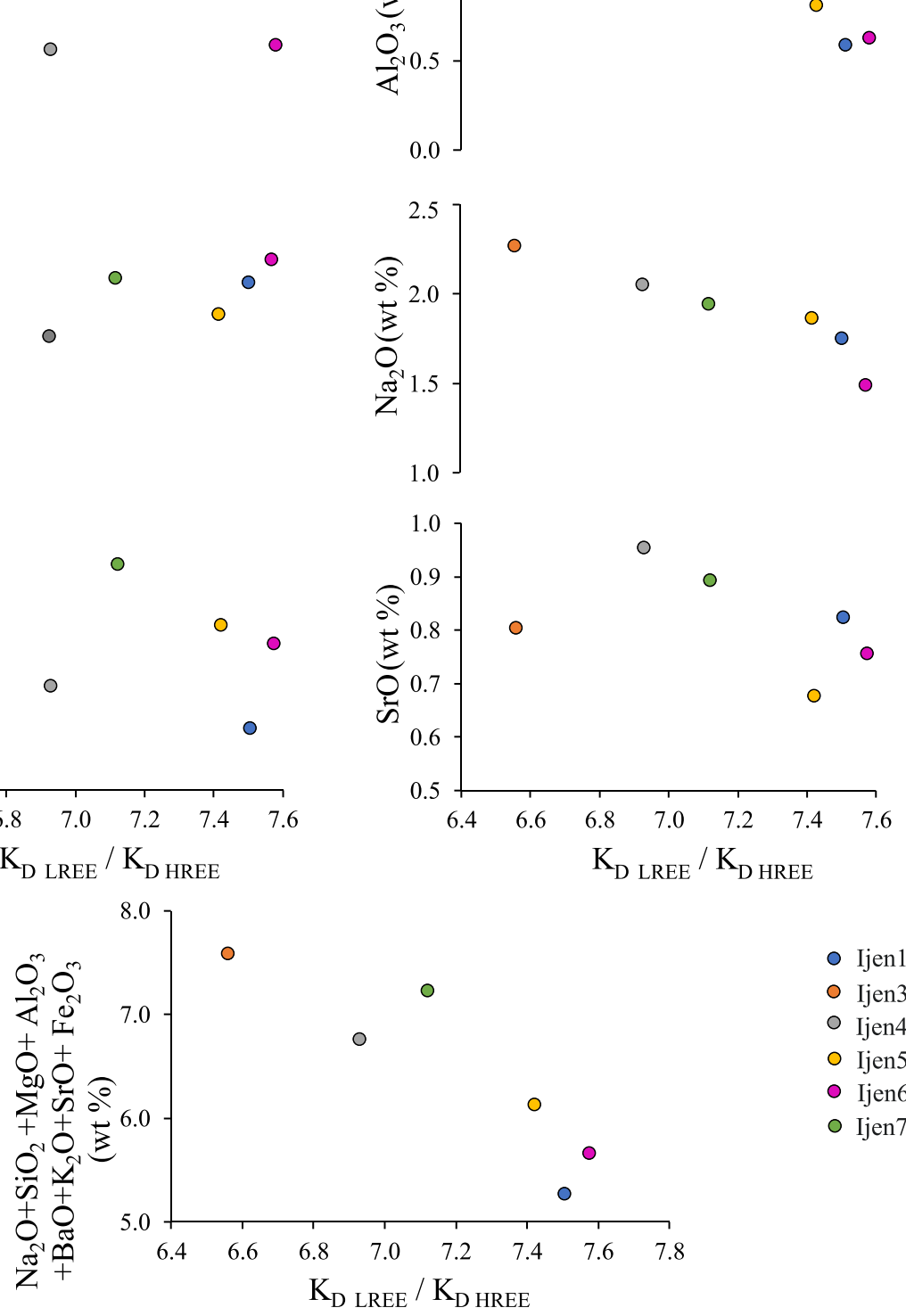

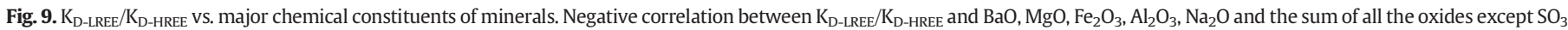
and $\mathrm{CaO}$. 
where $\left[R E E_{i}\right]_{s}$ and $\left[R E E_{i}\right]_{a q}$ are the concentrations of a selected $\left[R E E_{i}\right]$ (expressed in $\mu \mathrm{g} \mathrm{kg}^{-1}$ ) in the solid phase precipitated and the same $\left[R E_{i}\right]$ in aqueous solution from which it precipitated, respectively (Table 5). The REE $K_{D}$ values are similar for all the analyzed samples ranging from 18.4 to 0.7 , with values decreasing from $\mathrm{Pr}$ to $\mathrm{Lu}$ (Table 5; Fig. 8). The average $K_{D}$ values of Ce, Pr and Nd are quite similar ranging from 15.5 to 15.9. The average $\mathrm{K}_{\mathrm{D}}$ value of La is lower compared to those of $\mathrm{Ce}, \operatorname{Pr}$ and $\mathrm{Nd}$. The ratio between the LREE and HREE $\mathrm{K}_{\mathrm{D}}$ values $\left(\mathrm{K}_{\mathrm{D} \text {-LREE }} / \mathrm{K}_{\mathrm{D} \text {-HREE }}\right)$ was calculated by summing the $\mathrm{K}_{\mathrm{D}}$ values of the elements belonging to the two groups (LREE and HREE) and then dividing them. The $\mathrm{K}_{\mathrm{D} \text {-LREE }} / \mathrm{K}_{\mathrm{D} \text {-HREE }}$ ratio ranges from 6.6 to 7.6 showing a small variability of the $K_{D}$ patterns between the 6 samples investigated (Fig. 9). Fig. 9 shows that $\mathrm{K}_{\mathrm{D}-\mathrm{LREE}} / \mathrm{K}_{\mathrm{D} \text {-HREE }}$ ratio increases as the concentrations of $\mathrm{BaO}, \mathrm{MgO}, \mathrm{Fe}_{2} \mathrm{O}_{3}, \mathrm{Al}_{2} \mathrm{O}_{3}, \mathrm{Na}_{2} \mathrm{O}$ decrease. Similarly, the $\mathrm{K}_{\mathrm{D} \text {-LREE }} /$ $\mathrm{K}_{\mathrm{D} \text {-HREE }} \mathrm{VS}$. the sum of all the oxides except $\mathrm{SO}_{3}$ and $\mathrm{CaO}$ shows a negative trend (Fig. 9). These results highlight that the presence of secondary minerals other than gypsum cause the distribution coefficient $\left(K_{D}\right)$ variations observed in the studied samples. Moreover, this hypothesis is supported by the different pattern of REE in Al-sulphate mineral identified in the riverbed of the Banyu Pahit (Van Hinsberg et al., 2017) with respect to the REE in gypsum presented in this study (Fig. 6).

REE in waters normalized to the average Kawah Ijen magmatic rock have flat patterns, suggesting a near congruent dissolution of the average local rock (Fig. 5). LREE depletion in the original lake water was not recognized (Fig. 5; Table 4), while the precipitation of secondary minerals LREE enriched (mainly gypsum) from the lake water was identified in the experiment run at $\sim 25^{\circ} \mathrm{C}$ in laboratory (Table 5), temperature close to the lake water $\left(-33^{\circ} \mathrm{C}\right)$. The lack of a strong LREE depletion in the lake water, allows to suggest that LREE scavenging by sulphate minerals precipitated (mainly gypsum), can be insignificant relative to the supply of REE by rock dissolution. Changes in the REE patterns of lake water can occur as a function of the variations of the water physical-chemical -features, mainly related to the volcanic activity, possibly inducing the precipitation/dissolution of secondary minerals (Ayers, 2012; Varekamp, 2015; Inguaggiato et al., 2018).

Inguaggiato et al. (2018) discussed about the possible processes controlling the fractionation of REE during the precipitation of gypsum, supporting that surface scavenging and substitution of $\mathrm{Ca}^{2+}$ by REE within the crystalline structure are the processes responsible for the removal of REE from the solution. They concluded that is not possible to easily quantify the amount of REE scavenged on the mineral surface and the amount of REE that are hosted in crystal substituting the Ca.
On the other hand, Dutrizac (2017) proposed that the incorporation of REE in gypsum crystal takes place as consequence of the replacement of three $\mathrm{Ca}^{2+}$ ions by two $\mathrm{REE}^{3+}$ ions and a vacant $\mathrm{Ca}^{2+}$ lattice site. Recently, Lin et al. (2019) investigated $\mathrm{Gd}^{3+}$ incorporation in Gd-doped gypsum crystals confirming the structural incorporation of $\mathrm{Gd}^{3+}$ in gypsum via substitution of $\mathrm{Ca}^{2+}$, validating the role of the crystallographic control of gypsum removing Gd from water.

\subsection{Comparison between REE fractionation in Kawah Ijen and Poás hyper- acid volcano - hydrothermal lakes}

The Laguna Caliente crater lake of Poás volcano (Costa Rica) is a hyperacid lake characterized by similar physico-chemical features compared to the Kawah Ijen crater lake. As mentioned above, Inguaggiato et al. (2018) recently investigated the REE fractionation in the hyperacid brine of Laguna Caliente during the precipitation of secondary minerals (mainly gypsum as recognized by XRD analysis). It is a key point to compare the REE concentrations and the fractionation of REE due to the precipitation of secondary minerals in both the hyperacid lakes (Poás and Kawah Ijen lakes) in order to suggest a common fractionation process in arguably all the environments characterized by similar physicochemical features. Poás and Kawah Ijen lakes have similar pH, ranging from -0.3 to 0.2 and quite constant values around -0.27 , respectively. Laboratory experiments for both crater lakes were carried out at the same temperature $\left(\sim 25^{\circ} \mathrm{C}\right)$.

The REE in waters of Poás and Kawah Ijen crater lakes were normalized to the Post Archean Australian Shale (PAAS) and not to the average local rocks of the two different volcano-hydrothermal systems, in order to normalize the data of both volcanic lakes to the same reference material (Taylor and McLennan, 1985). Comparing the REE concentration in the water of Poás and Kawah Ijen crater lakes, it is possible to observe that both have similar REE patterns, slightly depleted in LREE with respect to the HREE (Fig. 10). Concentrations of REE dissolved in water are higher for Kawah Ijen lake water (5.86-6.52 $\mathrm{mg} \mathrm{kg}^{-1}$ ) compared to Poás lake water (1.14-2.18 $\mathrm{mg} \mathrm{kg}^{-1}$ ). Recent studies propose that the REE patterns in fluids are depleted in LREE as a consequence of the precipitation of hydrothermal minerals, such as the ones identified in this study, and point out the role in LREE fractionation of precipitating sulphate minerals (Varekamp, 2015; Peiffer et al., 2011; Inguaggiato et al., 2015, 2017, 2018). The $\sum$ REE in the solid phase ( 100\% gypsum) precipitated from Poás crater lake (23.7-33.0 $\mathrm{mg} \mathrm{kg}^{-1}$ ) is lower with respect to the one precipitated from the Kawah Ijen lake (59.5-78.6 $\mathrm{mg} \mathrm{kg}^{-1}$ ). REE in gypsum

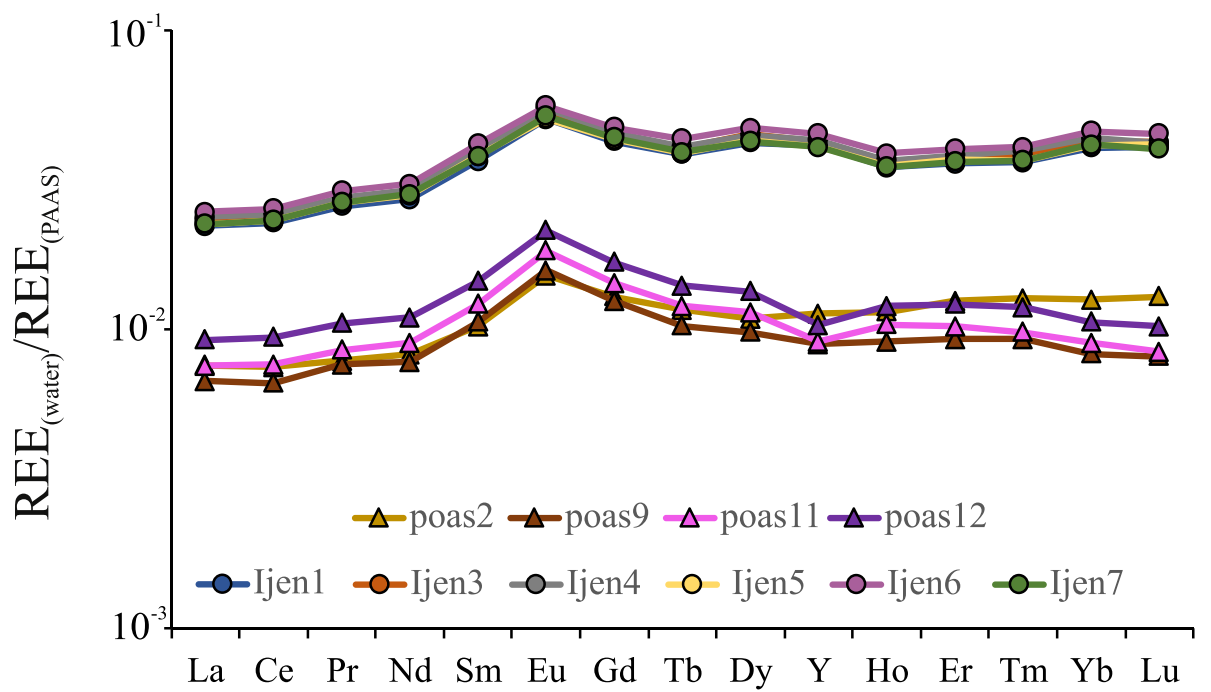

Fig. 10. Comparison between REE in the hyperacid waters of Kawah Ijen and Poás crater lakes normalized to PAAS. 


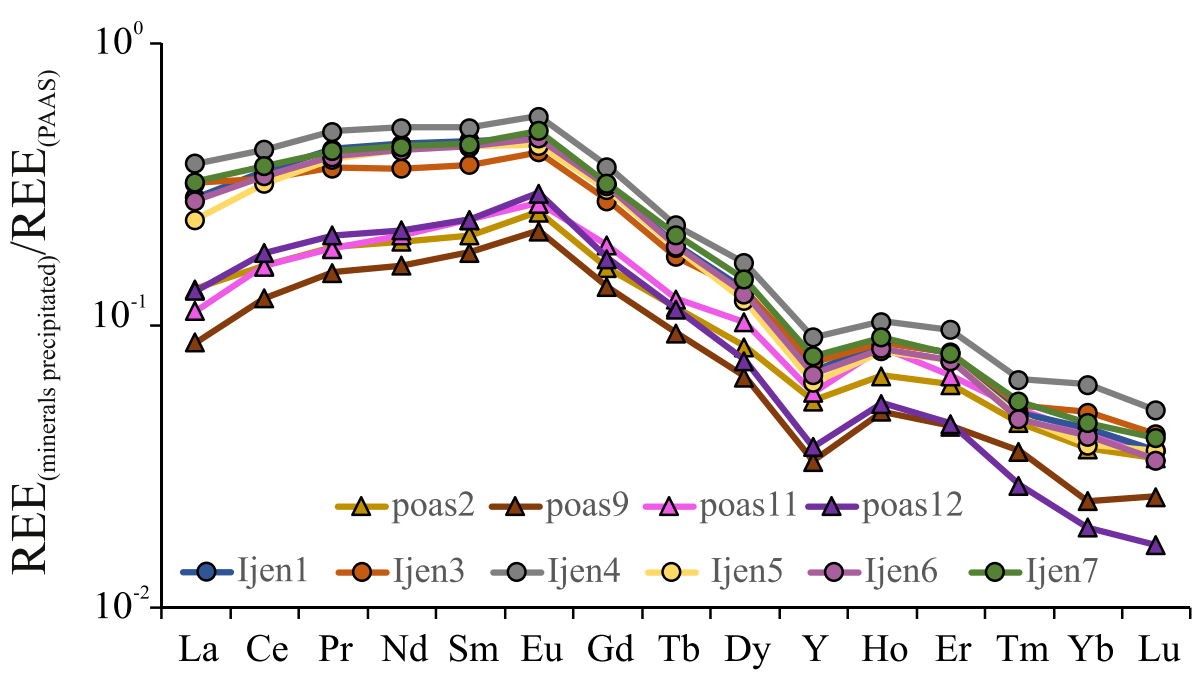

Fig. 11. Comparison between REE in the minerals precipitated (mainly gypsum) from the hyperacid waters of Kawah Ijen and Poás crater lakes normalized to PAAS.

normalized to the PAAS have similar patterns in Kawah Ijen and Poás lake, LREE strongly enriched compared to the HREE (Fig. 11). The highest concentrations found in the gypsum crystals of Kawah Ijen lake are due to the higher concentrations in the lake water compared to the concentration in Poás lake water (Figs. 10,11). The comparison of the REE $K_{D}$ calculated between the solid phases and the mother brines in Kawah Ijen and Poàs lakes (Fig. 12), suggests the occurrence of a similar fractionation process, characterized by a preferential removal of LREE during secondary mineral precipitation (mainly gypsum). $R E E K_{D}$ in both lakes is consistent with the distribution of REE found in the secondary minerals (mainly gypsum). The main difference of the REE $K_{D}$ is that the data obtained for Kawah Ijen lake are lower than the ones obtained for Poás Lake despite the higher concentration of REE in Kawah Ijen water. This could be related to the relative proportion of other sulphate minerals than gypsum, such as Alsulphate, alunite-jarosite, barite and celestite, in the solid phase precipitated. Further studies on the REE $K_{\mathrm{D}}$ during the precipitation of sulphate minerals, can quantify and confirm the effect on the fractionation of REE in water when additional sulphate minerals precipitate with gypsum.

The comparison between the two experiments allow to generalize that in other lakes with similar physico-chemical features as well as other hyperacid waters in volcano-hydrothermal systems, the precipitation of gypsum can be considered responsible of the LREE depletion in water. Moreover, the occurrence of LREE depletion in waters can be used as a geochemical tool to trace the sulphate minerals precipitation, especially gypsum.

\section{Conclusions}

The Kawah Ijen crater lake can be considered as a natural laboratory in order to investigate the REE behavior in hyperacid and hypersaline systems during sulphate minerals precipitation. The hyperacid sulphate-rich brine of Kawah Ijen crater lake is characterized by a high content of REE, ranging from 5.86 to $6.52 \mathrm{mg} \mathrm{kg}^{-1}$ suggesting that these extreme natural environments could be considered as possible unconventional reservoir. In the Kawah Ijen crater lake the high content of $\mathrm{SO}_{4}$ complemented by major and minor cation concentrations lead to the precipitation of sulphate-minerals, mainly gypsum and minor amounts of Al-sulphate (possible alunogen), Fe-K-sulphate (possible jarosite), and Ba, Sr-sulphate minerals (likely barite and/or celestite). Previous studies confirm the role of gypsum and suggest alunite and/or jarosite as the responsible of the fractionation of the REE in water. According to these studies, the gypsum here identified using XRD and electron microprobe analysis can be considered as a responsible of the REE fractionation in hyperacid crater lakes. REE concentration in the Kawah Ijen water lake (before precipitation of secondary minerals in laboratory) normalized to the unaltered magmatic local rock, reflects isochemical dissolution of the rock, while the LREE enriched patterns in the solid phase precipitated during the experiment (mainly gypsum), reflect the mobility of these elements from the water to the sulphate minerals (mainly gypsum). The negative correlation of $K_{D}$ (LREE) $/ K_{\mathrm{D} \text { (HREE) }}$ ratio with the sum of all the major chemical constituents

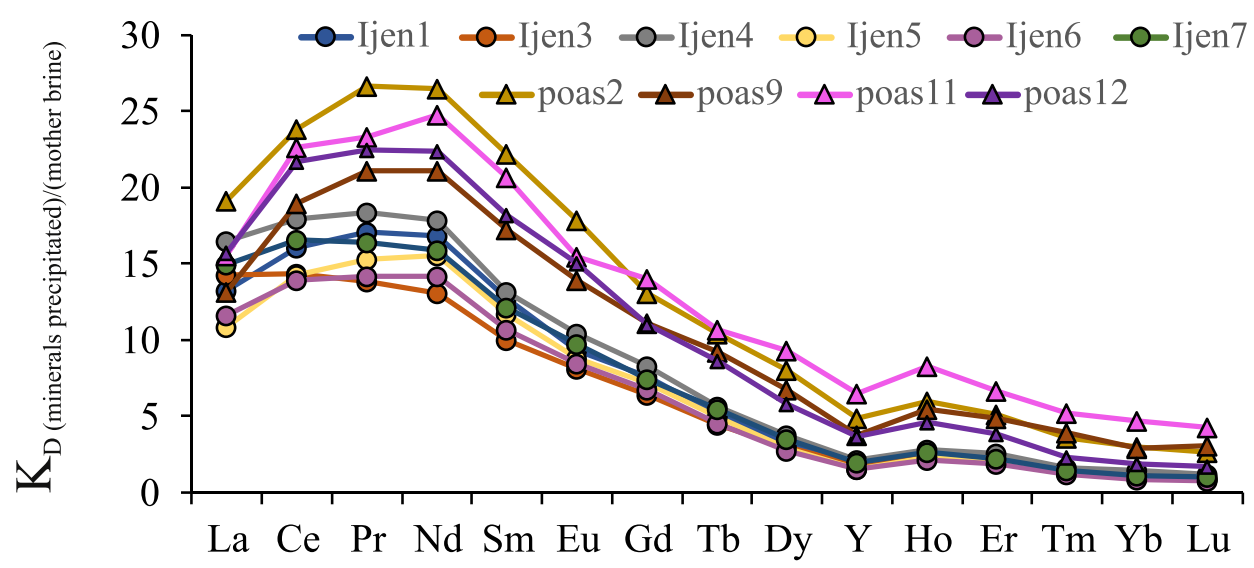

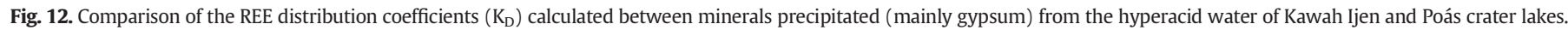


except $\mathrm{SO}_{3}$ and $\mathrm{CaO}$ in the precipitated solid phases, allow to suggest that the precipitation of others sulphate minerals as alunogen, jarosite, barite and celestite, even if in minor proportion compared to gypsum, affects the removal of REE from water via precipitation, possibly due to the different distribution coefficient of these minerals with respect to gypsum.

The comparison between the $\mathrm{K}_{\mathrm{D}}$ of REE in Kawah Ijen lake with that calculated in Poás lake during the precipitation of secondary minerals (mainly gypsum) allow to confirm that gypsum precipitation preferentially removes LREE with respect to HREE from the mother solution and that this process may occur in all the natural environments characterized by similar physico-chemical features as those of Kawah Ijen and Poás lakes.

\section{CRediT authorship contribution statement}

Claudio Inguaggiato: Conceptualization, Methodology, Writing original draft, Investigation, Writing - review \& editing, Resources. Sabrina Pappaterra: Writing - original draft, Writing - review \& editing, Conceptualization, Visualization. Loic Peiffer: Writing - review \& editing. Carmine Apollaro: Writing - review \& editing, Resources. Lorenzo Brusca: Resources, Validation. Rosanna De Rosa: Writing - review \& editing, Resources. Dmitri Rouwet: Writing - review \& editing. Corentin Caudron: Resources, Writing - review \& editing. Suparjan: Resources.

\section{Declaration of competing interest}

The authors declare that they have no known competing financial interests or personal relationships that could have appeared to influence the work reported in this paper.

\section{Acknowledgments}

We thank Dr. Johan C. Varekamp for the useful suggestions during the review process. Analysis and manipulation of the samples were carried out in the following laboratory: Istituto Nazionale di Geofisica e Vulcanologia, SLE-CT at Centro de Investigación Científica y de Educación Superior de Ensenada, Baja California (CICESE) and the Department of Biology, Ecology and Earth Sciences, Università della Calabria. This work has been partially developed under the financial support of the CICESE, internal project no 644163. The sampling campaign was executed during the "Wet Volcanoes Workshop" (VDAPUSGS and PVMBG, Indonesia; J. Pallister, C. Caudron and H. Gunawan).

\section{References}

Ayers, G., 2012. Behaviour of the REE during Water Rock Interaction and Alteration Processes in Volcanic Lake Systems. Ms thesis. Utrecht University, The Netherlands, pp. $1-108$.

Balaram, V., 2019. Rare earth elements: a review of applications, occurrence, exploration, analysis, recycling, and environmental impact. Geosci. Front. 10, 1285-1303.

Bau, M., Dulski, P., 1996. Anthropogenic origin of positive gadolinium anomalies in river waters. Earth Planet. Sci. Lett. 143, 245-255.

Caudron, C., Syahbana, D.K., Lecocq, T., Van Hinsberg, V., McCausland, W., Triantafyl-lou, A., Camelbeeck, T., Bernard, A., 2015. Kawah ijen volcanic activity: a review. Bull. Volcanol. 77 (3), 1-39.

Caudron, C., Campion, R., Rouwet, D., Lecocq, T., Capaccioni, B., Syahbana, D., Supergun Purwanto, B.H., Bernard, A., 2017. Stratification at the Earth's largest hyperacidic lake and its consequences. Earth Planet. Sci. Lett. 459, 28-35.

Censi, P., Cibella, F., Falcone, E.E., Cuttitta, G., Saiano, F., Inguaggiato, C., Latteo, V., 2017a. Rare earths and trace elements contents in leaves: a new indicator of the composition of atmospheric dust. Chemosphere 169, 342-350. https://doi.org/10.1016/j. chemosphere.2016.11.085.

Censi, P., Inguaggiato, C., Chiavetta, S., Schembri, C., Sposito, F., Censi, V., Zuddas, P., 2017b. The behaviour of zirconium, hafnium and rare earth elements during the crystallization of halite and other salt minerals. Chem. Geol. 453, 80-91. https://doi.org/ 10.1016/j.chemgeo.2017.02.003.

Censi, P., Raso, M., Yechieli, Y., Ginat, H., Saiano, F., Zuddas, P., Brusca, L., D’Alessandro, W., Inguaggiato, C., 2017c. Geochemistry of Zr, Hf and REE in a wide spectrum of eh and water composition: the case of Dead Sea fault system (Israel). Geochem. Geophys. Geosyst. 18, 1-14. https://doi.org/10.1002/2016GC006704.

Censi, P., Sposito, F., Inguaggiato, C., Zuddas, P., Inguaggiato, S., Venturi, M., 2018. Zr, Hf and REE distribution in river water under different ionic strength conditions. Sci. Total Environ. 645, 837-853. https://doi.org/10.1016/j.scitotenv.2018.07.081.

Colvin, A., Rose, W.I., Varekamp, J.C., Palma, J.L., Escobar, D., Gutierrez, E., Montalvo, F., Maclean, A., 2013. Crater lake evolution at Santa Ana volcano (El Salvador) following the 2005 eruption. Geol. Soc. Am. Spec. Pap. 498, 23-44.

Delmelle, P., Bernard, A., 1994. Geochemistry, mineralogy, and chemical modeling of the acid crater lake of Kawah Ijen volcano, Indonesia. Geochim. Cosmochim. Acta 58, 2445-2460.

Delmelle, P., Bernard, A., 2000. Downstream composition changes of acidic volcanic waters discharged into the Banyupahit stream, Ijen caldera, Indonesia. J. Volcanol. Geotherm. Res. 97, 55-75.

Delmelle, P., Bernard, A., 2015. The remarkable chemistry of sulfur in hyper-acid crater lakes: a scientific tribute to Bokuichiro Takano and Minoru Kusakabe. In: Rouwet, D., Christenson, B., Tassi, F., Vandemeulebrouck, J. (Eds.), Volcanic Lakes, pp. 239-258.

Delmelle, P., Bernard, A., Kusakabe, M., Fischer, T., Takano, B., 2000. Geochemistry of the magmatic-hydrothermal system of Kawah Ijen volcano, East Java, Indonesia. J. Volcanol. Geotherm. Res. 97, 31-53.

Dutrizac, J.E., 2017. The behaviour of the rare earth elements during gypsum $\left(\mathrm{CaSO}_{4} \cdot 2 \mathrm{H}_{2} \mathrm{O}\right)$ precipitation. Hydrometallurgy 174, 38-46.

Emsbo, P., Patrick, I., McLaughlin, P.I., Breit, G.N., Du Bray, E.A., Koenig, A.E., 2015. Rare earth elements in sedimentary phosphate deposits: solution to the global REE crisis? Gondwana Res. 27, 776-785.

Franus, W., Wiatros-Motyka, M.M., Wdowin, M., 2015. Coal fly ash as a resource for rare earth elements. Environ. Sci. Pollut. R. 22, 9464-9474.

Gunawan, H., Caudron, C., Pallister, J., Primulyana, S., Christenson, B., McCausland, W., van Hinsberg, V., Lewicki, J., Rouwet, D., Kelly, P., Kern, C., Werner, C., Johnson, J.B., Utami, S.B., Syahbana, D.K., Saing, U., Suparjan, Purwanto, B.H., Sealing, C., Martínez Cruz, M., Maryanto, S., Bano, P., Laurin, A., Schmid, A., Bradley, K., Nandaka, I.G.M.A., Hendrasto, M., 2016. New insights into Kawah Ijen's volcanic system from the wet volcano workshop experiment. In: Ohba, T., Capaccioni, B., Caudron, C. (Eds.) Geochemistry and Geophysics of Active Volcanic Lakes, Geol. Soc. London, Special Publications 437. doi: https://doi.org/10.1144/SP437.7.

Hammas-Nasri, I., Horchani-Naifer, K., Férid, M., Barca, D., 2016. Rare earths concentration from phosphogypsum waste by two-step leaching method. Int. J. Miner. Process. 149, 78-83.

Henley, R.W., 2015. Hyperacidic volcanic lakes, metal sinks and magmatic gas expansion in arc volcanoes. In: Rouwet, D., Christenson, B.W., Tassi, F., Vandemeulebrouck, J. (Eds.), Volcanic Lakes. Springer, Berlin, pp. 155-178.

Inguaggiato, C., Censi, P., Zuddas, P., Londoño, J.M., Chacón, Z., Alzate, D., Brusca, L., D'Alessandro, W., 2015. Geochemistry of REE, $\mathrm{Zr}$ and $\mathrm{Hf}$ in a wide range of $\mathrm{pH}$ and water composition: the Nevado del Ruíz volcano-hydrothermal system (Colombia). Chem. Geol. 417, 125-133. https://doi.org/10.1016/j.chemgeo.2015.09.025.

Inguaggiato, C., Censi, P., Zuddas, P., D'Alessandro, W., Brusca, L., Pecoraino, G., Bellomo, S., 2016. Zirconium-hafnium and rare earth element signatures discriminating the effect of atmospheric fallout from hydrothermal input in volcanic lake water. Chem. Geol. 433, 1-11. https://doi.org/10.1016/j.chemgeo.2016.04.002.

Inguaggiato, C., Burbano, V., Rouwet, D., Garzon, G. 2017. Geochemical processes assessed by rare earth elements fractionation at "Laguna Verde" acidic-sulphate crater lake (Azufral volcano, Colombia). Appl. Geochem. 79, 65-74. https://doi.org/10.1016/j. apgeochem.2017.02.013.

Inguaggiato, C., Iñiguez, E., Peiffer, L., Kretzschmar, T., Brusca, L., Mora-Amador, R., Ramirez, C., Bellomo, S., Gonzalez, G., Rouwet, D., 2018. REE fractionation during the gypsum crystallization in hyperacid sulphate-rich brine: the Poás volcano crater lake (Costa Rica) exploited as laboratory. Gondwana Res. 59, 87-96. https://doi.org/ 10.1016/j.gr.2018.02.022.

Johannesson, K., Stetchenbach, K., Hodge, V., 1997. Rare earth elements as geochemical tracers of regional groundwater mixing. Geochim. Cosmochim. Acta 61, 3605-3618.

Kalacheva, E., Taran, Y., Kotenko, T., 2015. Geochemistry and solute fluxes of volcanohydrothermal systems of Shiashkotan, Kuril Islands. J. Volcanol. Geotherm. Res. 296, 40-54.

Kato, Y., Fujinaga, K., Nakamura, K., Takaya, Y., Kitamura, K., Ohta, J., Toda, R., Nakashima, T., Iwamori, H., 2011. Deep-sea mud in the Pacific Ocean as a potential resource for rare-earth elements. Nat. Geosci. 4, 535-539.

Kikawada, H., Oi, T., Honda, T., Ossaka, T., Kakihana, H., 1993. Lanthanoid abundances of acidic hot spring and crater lake waters in the Kusatsu-Shirane volcano region, Japan. Geochem. J. 27, 19-33.

Kolokolnikov, V.A., Kovalev, M.I., 2009. Processing rare-earth element concentrate obtained from phosphogypsum. Chem. Sustain. Dev. 17, 261-266.

Lawrence, M.G., Greig, A., Collerson, K.D., Kamber, B.S., 2006. Direct quantification of rare earth element concentrations in natural waters by ICP-MS. Appl. Geochem. 21, 839-848. https://doi.org/10.1016/j.apgeochem.2006.02.013.

Lewis, A.J., Komninou, A., Yardley, B.W., Palmer, M.R., 1998. Rare earth element speciation in geothermal fluids from Yellowstone National Park, Wyoming, USA. Geochim. Cosmochim. Acta 62, 657-663.

Liang, H., Zhang, P., Jin, Z., DePaoli, D., 2017. Rare earths recovery and gypsum upgrade from Florida phosphogypsum. Miner. Metall. Process. 34, 201-206.

Lin, J., Nilges, M.J., Wiens, E., Chen, N., Wang, S., Pan, Y., 2019. Mechanism of Gd ${ }^{3+}$ uptake in gypsum $\left(\mathrm{CaSO}_{4} \cdot 2 \mathrm{H}_{2} \mathrm{O}\right)$ : implications for EPR dating, REE recovery and REE behavior. Geochim. Cosmochim. Acta 258, 63-78.

Michard, A., 1989. Rare earth element systematics in hydrothermal fluids. Geochim. Cosmochim. Acta 53, 745-750. 
Moreno, T., Querol, X., Alastuey, A., Gibbons, W., 2008. Identification of FCC refinery atmospheric pollution events using lanthanoid- and vanadium-bearing aerosols. Atmos. Environ. 42, 7851-7861.

Noack, C.W., Dzombak, D.A., Karamalidis, A.K., 2014. Rare earth element distributions and trends in natural waters with a focus on groundwater. Environ. Sci. Technol. 48, 4317-4326.

Palmer, S., Van Hinsberg, V.J., McKenzie, J.M., Yee, S., 2011. Characterization of acid river dilution and associated trace element behavior through hydrogeochemical modeling: a case study of the Banyu Pahit River in East Java, Indonesia. Appl. Geochem. 26, 1802-1810.

Parreira, A.B., Kobayashi Jr., A.R.K., Silvestre, O.B., 2003. Influence of Portland cement type on unconfined compressive strength and linear expansion of cement stabilized phosphogypsum. J. Environ. Eng. 129, 956-960.

Peiffer, L., Taran, Y.A., Lounejeva, E., Solís-Pichardo, G., Rouwet, D., Bernard-Romero, R.A. 2011. Tracing thermal aquifers of El Chichón volcano-hydrothermal system (México) with ${ }^{87} \mathrm{Sr} /{ }^{86} \mathrm{Sr}, \mathrm{Ca} / \mathrm{Sr}$ and REE. J. Volcanol. Geotherm. Res. 205, 55-66.

Rillard, J., Pourret, O., Censi, P., Inguaggiato, C., Zuddas, P., Toulhoat, P., Gombert, P., Brusca, $\mathrm{L} ., 2019$. Behavior of rare earth elements in an aquifer perturbed by $\mathrm{CO}_{2}$ injection: environmental implications. Sci. Total Environ. 687, 978-990. https://doi.org/10.1016/j. scitotenv.2019.05.490.

Rouwet, D., Tassi, F., Mora-Amador, R., Sandri, L., Chiarini, V., 2014. Past, present and future of volcanic lake monitoring. J. Volcanol. Geotherm. Res. 272, 78-97.

Takano, B., Suzuki, K., Sugimori, K., Ohba, T., Fazlullin, S.M., Bernard, A., Sumarti, S., Sukhyar, R., Hirabayashi, M., 2004. Bathymetric and geochemical investigation of Kawah Ijen crater Lake, East Java, Indonesia. J. Volcanol. Geotherm. Res. 135, 299-329.

Taran, Y., Rouwet, D., Inguaggiato, S., Aiuppa, A., 2008. Major and trace element geochemistry of neutral and acidic thermal springs at El Chichón volcano, Mexico. Implications for monitoring of the volcanic activity. J. Volcanol. Geotherm. Res. 178, 224-236.

Tayibi, H., Choura, M., Lopez, F.A., Alguacil, F.J., Lopez-Delgado, A., 2009. Environmental impact and management of phosphogypsum. J. Environ. Manag. 90, 2377-2386.
Taylor, S.R., McLennan, S.M., 1985. The Continental Crust: Its Composition and Evolution. Blackwell, Oxford.

Van Hinsberg, V., Berlo, K., Sumarti, S., Van Bergen, M., Williams-Jones, A., 2010. Extreme alteration by hyperacidic brines at Kawah Ijen volcano, East Java, Indonesia: II. Metasomatic imprint and element fluxes. J. Volcanol. Geotherm. Res. 196, 169-184.

Van Hinsberg, V., Vigouroux, N., Palmer, S., Berlo, K., Mauri, G., Williams-Jones, A., McKenzie, J., Williams-Jones, G., Fischer, T., 2017. Element flux to the environment of the passively degassing Kawah Ijen volcano, Indonesia, and implications for estimates of the global volcanic flux. From. In: Ohba, T., Capaccioni, B., Caudron, C. (Eds.), Geochemistry and Geophysics of Active Volcanic Lakes. Geological Society London, Special Publications, p. 437. https://doi.org/10.1144/SP437.2.

Varekamp, J.C., 2015. The chemical composition and evolution of volcanic lakes. In: Rouwet, D., Christenson, B., Tassi, F., Vandemeulebrouck, J. (Eds.), Volcanic Lakes, pp. 93-123.

Varekamp, J.C., Pasternack, G.B., Rowe, G.L., 2000. Volcanic lake systematics. II. Chemical constraints. J. Volcanol. Geotherm. Res. 97, 161-179.

Varekamp, J.C., Ouimette, A.P., Herman, S.W., Flynn, K.S., Bermudez, A., Delpino, D., 2009. Naturally acid waters from Copahue volcano, Argentina. Appl. Geochem. 24 (2), 208-220.

Vigouroux, N., Wallace, P.J., Williams-Jones, G., Kelley, K., Kent, A.J.R., Williams-Jones, A.E. 2012. The sources of volatile and fluid-mobile elements in the Sunda arc: a melt inclusion study from Kawah Ijen and Tambora volcanoes, Indonesia. Geochem. Geophys. Geosyst. 13.

Woitischek, J., Dietzel, M., Inguaggiato, C., Böttcher, M.E., Albrecht, L., Virgílio Cruz, J., Gehre, M., 2017. Characterisation and origin of hydrothermal waters at São Migue (Azores) inferred by chemical and isotopic composition. J. Volcanol. Geotherm. Res. https://doi.org/10.1016/j.jvolgeores.2017.03.020.

Wood, S.A., 2006. Rare earth element systematics of acidic geothermal waters from the Taupo volcanic zone, New Zealand. J. Geochem. Explor. 89, 424-427. 